\title{
Forty-five years of oceanographic and meteorological observations at a coastal station in the NW Mediterranean: a ground truth for satellite observations
}

\author{
Jordi Salat $^{1}$ (D) Josep Pascual ${ }^{1} \cdot$ Mar Flexas $^{2} \cdot$ Toshio Michael Chin $^{3} \cdot$ Jorge Vazquez-Cuervo $^{3}$
}

Received: 1 November 2018 / Accepted: 20 June 2019 / Published online: 9 August 2019

(C) The Author(s) 2019

\begin{abstract}
Marine and atmospheric parameters, including temperature observations from surface to $80 \mathrm{~m}$ (at 6 depths) are measured since September 1973 on a higher-than-weekly frequency, at a coastal station 4 km offshore L'Estartit (Costa Brava; NW Mediterranean). This constitutes the longest available uninterrupted oceanographic time series in the Mediterranean Sea. The present contribution focuses on observed climatic trends in temperature $\left({ }^{\circ} \mathrm{C} /\right.$ year) of air (AT; 0.05), sea surface (SST; 0.03$)$, sea at $80 \mathrm{~m}$ depth (S80T; 0.02) and sea level (SL; $3.1 \mathrm{~mm} /$ year) as well as comparison with trends estimated from coincident highresolution satellite data. The trending evolution is not uniform across seasons, being significantly higher in spring for both AT and SST, while in autumn for S80T. Other climatological results are a stratification increase $\left(0.02{ }^{\circ} \mathrm{C} /\right.$ year in summer temperature difference between $20 \mathrm{~m}(\mathrm{~S} 20 \mathrm{~T})$ and S80T), trends in summer conditions at sea (when S20T $>18^{\circ} \mathrm{C}$ ), estimated as 0.5 and 0.9 days/year for the starting day and period respectively, and a decreasing trend of nearly 2 days/year in the period of conditions favourable for marine evaporation (when AT < SST). This last trend may be related to the observed decrease of coastal precipitation in spring. The long-term consistency in the in situ SST measurements presents an opportunity to validate the multi-decadal trends. The good agreement for 2013-2018 (RMS 0.5-0.6, bias -0.1 to -0.2 ; trends of $0.09{ }^{\circ} \mathrm{C} / \mathrm{year}$ in situ vs. 0.06 to $0.08{ }^{\circ} \mathrm{C}$ year from satellite) allows considering this observational site as ground truth for satellite observations and a monitoring site for climate change.
\end{abstract}

Keywords Oceanographic time series $\cdot$ Climate trends $\cdot$ Satellite ground truth $\cdot$ Stratification $\cdot$ Seasonality $\cdot$ Mediterranean Sea

\section{Introduction}

Long-term monitoring sites are scarce in the world ocean. Most of the financial sources have been traditionally addressed to achieve short-term oceanographic objectives. In

This article is part of the Topical Collection on the 50th International Liège Colloquium on Ocean Dynamics, Liège, Belgium, 28 May to 1 June 2018

Responsible Editor: Michael J. McPhaden

Jordi Salat

salat@icm.csic.es

1 Institut de Ciencies del Mar, ICM/CSIC, Passeig Marítim de la Barceloneta, 37-49, 08003 Barcelona, Spain

2 California Institute of Technology, 1200 E. California Boulevard, Pasadena, CA 91125, USA

3 Jet Propulsion Laboratory, California Institute of Technology, 4800 Oak Grove Dr., Pasadena, CA 91109, USA comparison with weather stations, that were required to produce weather forecasts, there was absence of equivalent oceanographic forecasts. There was a general lack of acknowledgement that an oceanographic equivalent was necessary, possibly because the sea state depends essentially on winds, and marine traffic does not directly depend upon ocean temperature or salinity. Oceanographic information was known to be useful for fisheries, but does not have an immediate impact as to require high-frequency monitoring. Indeed, ocean motion is slow, and it was a widespread perception that ocean properties change smoothly. There was also clear evidence that ocean data acquisition costs were much higher than their atmospheric counterpart. Thus, early oceanographic efforts focused on producing maps of oceanic circulation and water masses. The underlying idea was that these properties could be considered as a permanent background, with some degree of variability (that is, a mean value with more or less variance).

Two of the first parameters that were regularly monitored were sea level and sea state, essentially because of their impact 
on shores, coastal equipment and harbours. Reconstructions of the oceanic history were derived from the comparison of data obtained from different oceanographic cruises. Although data was collected under diverse projects, comparisons evidenced that changes at sea were more rapid and much less smooth than foreseen. In most cases, such cruises had no common purpose nor belonged to any monitoring program.

By the end of the last century, the concept of Operational Oceanography emerged as an equivalent to the weather reports, with the associated requirement of regular monitoring. Other drivers fostering oceanographic monitoring have been the need to evaluate anthropogenic contributions to climate change. Although the relation between the ocean and climate is not new, it is recently vindicated in many papers with a classical introduction justifying the interest of ocean monitoring, satellite observations, modelling exercises or altogether. During the 1980s, when signs of a heating trend on climate started to be evident, international programs such as the World Ocean Circulation Experiment (WOCE 1988) started to foster long-term oceanographic studies. It was recognized "that successful simulation of the broad evolution of global climate beyond a few years will require the inclusion of the world oceans through their full depth". For the first time, a global pattern of oceanographic observations was established, with common methodologies that could be repeated-most of them have indeed been repeated several times - enabling interesting comparisons related to the impact ocean circulation on climate and vice-versa (e.g. Bryden et al. 2005; Ganachaud et al. 2000).

Nowadays, it is widely accepted that monitoring the ocean properties provides valuable information on climatological (long-term) mean values, variability ranges and long-term changes or trends. The recent growth of technological innovations fostered oceanic monitoring to unprecedented levels: from sea surface to ocean floor, from coast to open seas, by means of satellite, drifters, gliders, moorings, buoys, Argo profilers, ships of opportunity, as well as the classical oceanographic cruises. These networks are producing massive amounts of data that are then used, in near real-time or in data-assimilative models, to produce ocean state estimations and oceanic forecasts, and to give estimates of climate trends. This is, however, a very recent situation in terms of climate evolution, involving not more than the last 20-30 years. Forecasts and predictions face strong data constraints and challenges, including uncertainty quantification, due to the lack of long oceanic time series.

Indeed, long time series of ocean properties are rare in the surface ocean, and even rarer in the deep ocean. In days past, most of these initiatives took advantage of the presence of coastal laboratories that promoted fixed oceanographic stations easily reachable from their onshore installations. One example of fixed oceanographic stations is the California Cooperative Oceanic Fisheries Investigations (CalCOFI), formed in 1949 to study the ecological aspects of the sardine population collapse off California. Today, their focus has shifted to the study of the marine environment off the coast of California, the management of its living resources and monitoring the indicators of El Niño and climate change. CalCOFI conducts quarterly cruises off southern and central California, collecting a suite of hydrographic and biological data on station and while underway (Bograd et al. 2003). The North Atlantic region is an unusual example of long-term monitoring. It has a relatively large number of locations at which oceanographic data have been collected repeatedly for many years or decades; the longest records go back more than a century (e.g. ICES data sets). In the Mediterranean Sea, oceanographic data series during the last century are more scarce and unevenly distributed. One of the oldest fixed oceanographic stations is the observing point $B$ in the Villefranche sur Mer bay (Ligurian Sea; France) that started weekly oceanographic data collection in May 1957 (Bougis and Carré 1960). Observations in this point have been maintained up to now although with several interruptions.

Likely due to the financial restrictions mentioned earlier, many of the atmosphere and oceanic long time series initiatives started (or were in part maintained) as a non-governmental, non-profit, voluntary initiative. One famous example is the oldest climate time series, the Mauna-Loa station, whose data was used as evidence for anthropogenic increase of the $\mathrm{CO}_{2}$ concentration in the atmosphere. Similar origin had many initiatives collecting relevant oceanographic data. For example, the Oceanographic Society of Gipuzkoa has recorded sea surface temperature (SST) measurements in Donostia (southeastern Bay of Biscay; Spain), on a nearly daily basis since July 1946, providing more than 70 years of SST measurements to analyse local hydrographic trends and anomalies (Goikoetxea et al. 2009). The present paper refers to another of these voluntary initiatives: the Meteorological and Oceanographic coastal station at L'Estartit (Costa Brava, NW Mediterranean; Spain) that is carrying out weekly oceanographic observations uninterruptedly since September 1973. These data provide a unique opportunity for comparisons with satellite-derived SST in coastal regions. This paper aims to be not only a tribute to its origins and its scientific value, but also a wake-up call to start, today, similar initiatives and to insure their continuity through time.

The paper is outlined as follows. In section 2, we present the history of the L'Estartit station and the data sets produced, detailing the methods used to record each type of observation. In section 3, the methods to calculate climatic trends for the selected variables such as air, sea surface and sub-surface temperatures, changes in stratification, estimates of favourable conditions for evaporation (from the number of days during which sea surface temperature is higher than air temperature), sea level and precipitation. Methodology for Satellite SST products is also presented in this section. In section 4, we 
present the results obtained from the L'Estartit data. Section 5 places our results in a general context and are compared with previous works in the region and those based on L'Estartit data sets and compares the observed in situ SST with the available satellite products and their trends. Some general conclusions are outlined in section 6 .

\section{L'Estartit data set}

\subsection{History and environmental considerations}

As early as in 1969, Josep Pascual started a series of daily meteorological observations, measuring precipitation, air temperature and atmospheric pressure at L'Estartit, a small coastal town in the Catalan Costa Brava (NW Mediterranean). Later on, in September 1973, the inland meteorological observations were complemented with sea temperature observations at an ocean point located a few miles offshore (Fig. 1). L'Estartit is located at the north side of a small bay. It has a small harbour open to the SE and there are several small islands closing the bay. A hill, $228 \mathrm{~m}$ high, dominates the coastal cliff.

Ocean observations at a fixed point (AA) at about $4 \mathrm{~km}$ offshore L'Estartit, away from the bay and the islands, were obtained using calibrated reversing thermometers at 4 to 7 fixed levels, from surface to $80 \mathrm{~m}$ depth, with an average frequency of at least once per week, weather permitting, resulting in 60 to 80 visits per year, uninterrupted until today. The station, although quite close to shore, is located at the southern limit of the relatively narrow continental shelf, at the coastal side of the main along-slope current in the NW Mediterranean, the Northern Current, that flows in SW direction from the Ligurian Sea to near the Alboran Sea. Oceanographic conditions at this site are representative of those found upstream, at the southern limit of the continental shelf of the Gulf of Lions (Font et al. 1988).

Additional observations (mostly still on paper, not yet converted onto digital format) on marine environmental conditions at sight, such as water transparency (Secchi disc), clouds, sea-state, presence of birds, medusae or marine mammals and surface roughness and visual surface currents at several points along the track across the islands to reach the point AA were also recorded (Fig. 2). Inland meteorological observations of daily air temperature, precipitation, atmospheric pressure and humidity started in 1969. With time, these have been progressively complemented with potential daily evaporation (Piché) since 1976, and with sea state, wind speed and direction measurements since 1988. Since 1990, continuous analogic sea level data has been collected by a tide gauge installed inside the harbour (Fig. 3). Finally, since early 1990s, conductivity-temperature-depth (CTD) profiles along the track across the islands, and water samples for salinity analysis were also occasionally collected.

The zone near the station was declared marine-protected area (MPA) in 1990 (within the Parc Natural del Montgri, les Illes Medes $i$ el Baix Ter). The station is still maintained by Josep Pascual, as a voluntary observer, with the collaboration of the Institut de Ciències del Mar (CSIC) and the authority of the MPA. The series of observations is the longest uninterrupted within the Mediterranean Sea. Data (detailed in Table 1) are free and digitised data can be accessed upon demand (http://meteolestartit.cat/).

\subsection{Data set}

The main station (AA) is $90 \mathrm{~m}$ deep and located at $\sim 42^{\circ}$ $03^{\prime} \mathrm{N}, 3^{\circ} 15^{\prime} \mathrm{E}$ (Fig. 1). The average frequency of observations is higher than once per week $(\sim 60$ to +100 visits per year). Sea temperatures have been obtained using two Richter and Wiese protected reversing thermometers mounted on a Nansen bottle. Temperature readings, after correction according to the thermometer's calibration certificates, are averaged if the temperature difference among thermometers is lower than $0.2{ }^{\circ} \mathrm{C}$ and repeated otherwise, so that the accuracy can be set to be lower than $0.2{ }^{\circ} \mathrm{C}$. Thermometers are periodically controlled at facilities of the Marine Research Institute (ICM) in Barcelona against a high-precision $\mathrm{Pt}_{100}$. which, in turn, is annually controlled using $\mathrm{Ga}$ and pure $\mathrm{H}_{2} \mathrm{O}$ melting points. Sea level gauge is a mechanical device attached to a continuous graphical recorder (Fig. 3). The record is digitized at 2-h interval and the originals preserved for detailed analyses if necessary. The position is periodically georeferenced by the Catalan Cartographic Institute (ICC) every 5 years and data is backwards linearly corrected for each period.

Atmospheric parameters (air temperature, pressure, relative humidity, precipitation and potential evaporation, Piché) have been measured in a meteorological box with standard instruments certified and regularly checked by the Spanish Meteorological Office (AEMET). These observations have been included in the official AEMET weather observation network. The meteorological box is located in front of the harbour at the sea level. Wind measurements at this location are not representative of the coastal zone because of the shelter from buildings and the coastal hills. For that reason, an anemometer is located on top of the hill, free of any sheltering. The anemometer is also controlled and certified by the Meteorological Office. Wind velocities and direction on top of the hill are very similar with those regularly measured offshore at the station AA ( Wind velocities measured at the harbour station are 

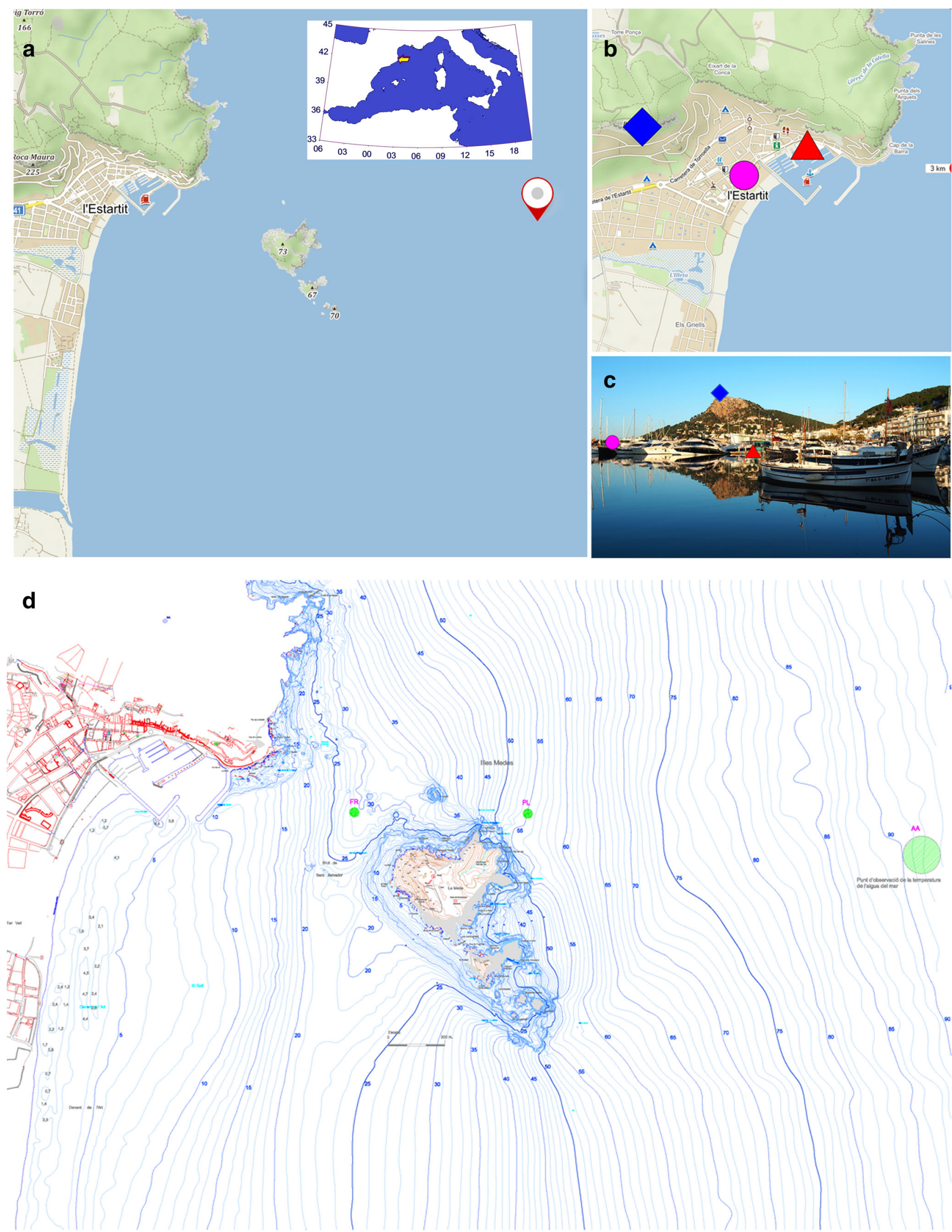

Fig. 1 Observational setting. Reference map for the position of station AA (a). Location of meteorological box (magenta circle), sea level gauge (red triangle), wind station (blue diamond) on a map (b), and on a picture (c), and bathymetric chart of the area (d) 


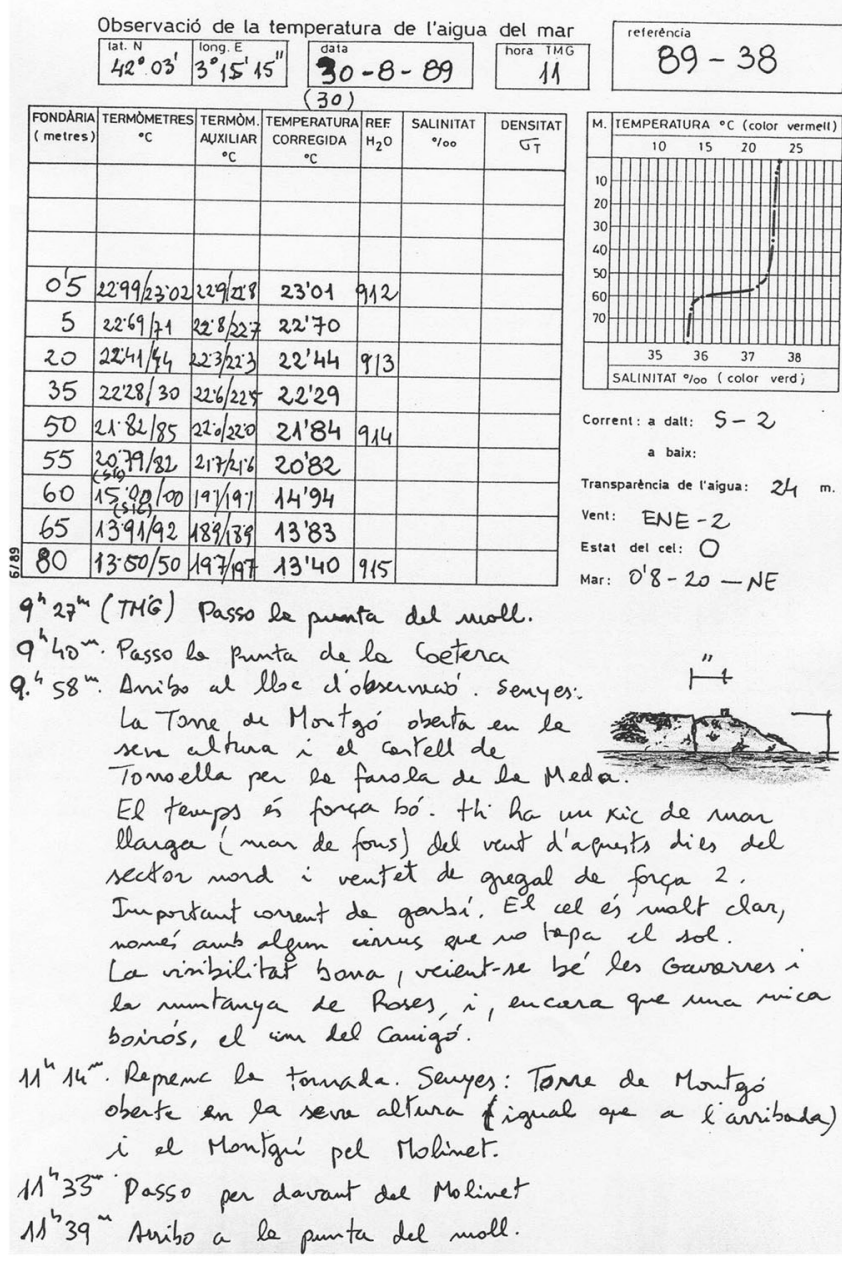

Fig. 2 Example of daily logs

typically $\sim 10 \%$ of the actual open sea values for low to moderate winds. For higher winds $(>15 \mathrm{~m} / \mathrm{s})$, the relation increases up to $20 \%$ due to the strong local turbulence near the harbour.

Data sets of monthly-averaged data for air temperature, sea level and sea temperatures at surface, 20, 50 and $80 \mathrm{~m}$, as well as monthly precipitation, up to December 2018, that have been used for the present paper, can be found and freely accessed through the PANGAEA repository (https://doi.org/10.1594/PANGAEA.902591) (Pascual and Salat 2019).

\section{Methodology}

\subsection{Trend estimations for in situ observations and derived parameters}

For climate trend analyses, the primary measurements (all temperatures and sea level) have been monthly averaged. To remove the seasonal cycle, monthly anomalies are calculated

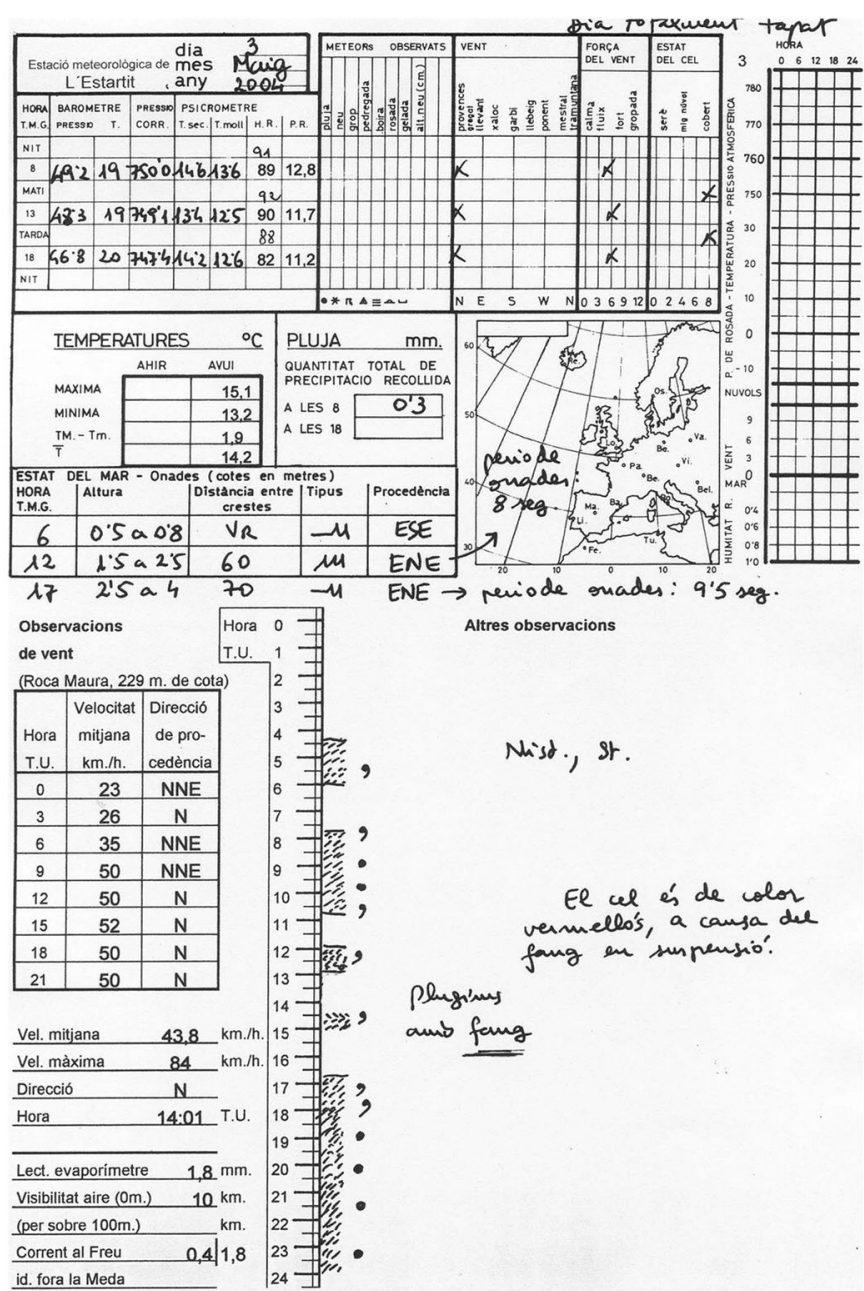

by subtracting the monthly-averaged climatology (calculated over 45 years of data). The total number of data points for each trend estimation is thus 540 . Trends are obtained by linear regression of the anomalies and converted into values-peryear (per annum). Significance of the trend estimates is evaluated using the " $t$ test" compared against a "null hypothesis" of no trend (zero trend value). The confidence interval is computed based on the significance level $\alpha=0.01$ (99\% confidence). The associated " $p$ value", stating the probability of observing the given trend under the null hypothesis, quantifies how rare it is to observe such a trend only by chance.

Seasonal trends have been computed selecting January, February and March anomalies for the winter season, and so on for the rest of the seasons. Trends are always expressed in rates of variation per annum. The total number of data points for each seasonal trend is thus 135. Precipitation has been seasonally and annually accumulated so that the total number of precipitation data points is 45 either for annual and seasonal trends.

In temperate seas, the annual cycle of the water column show the formation and subsequent deepening of a seasonal 

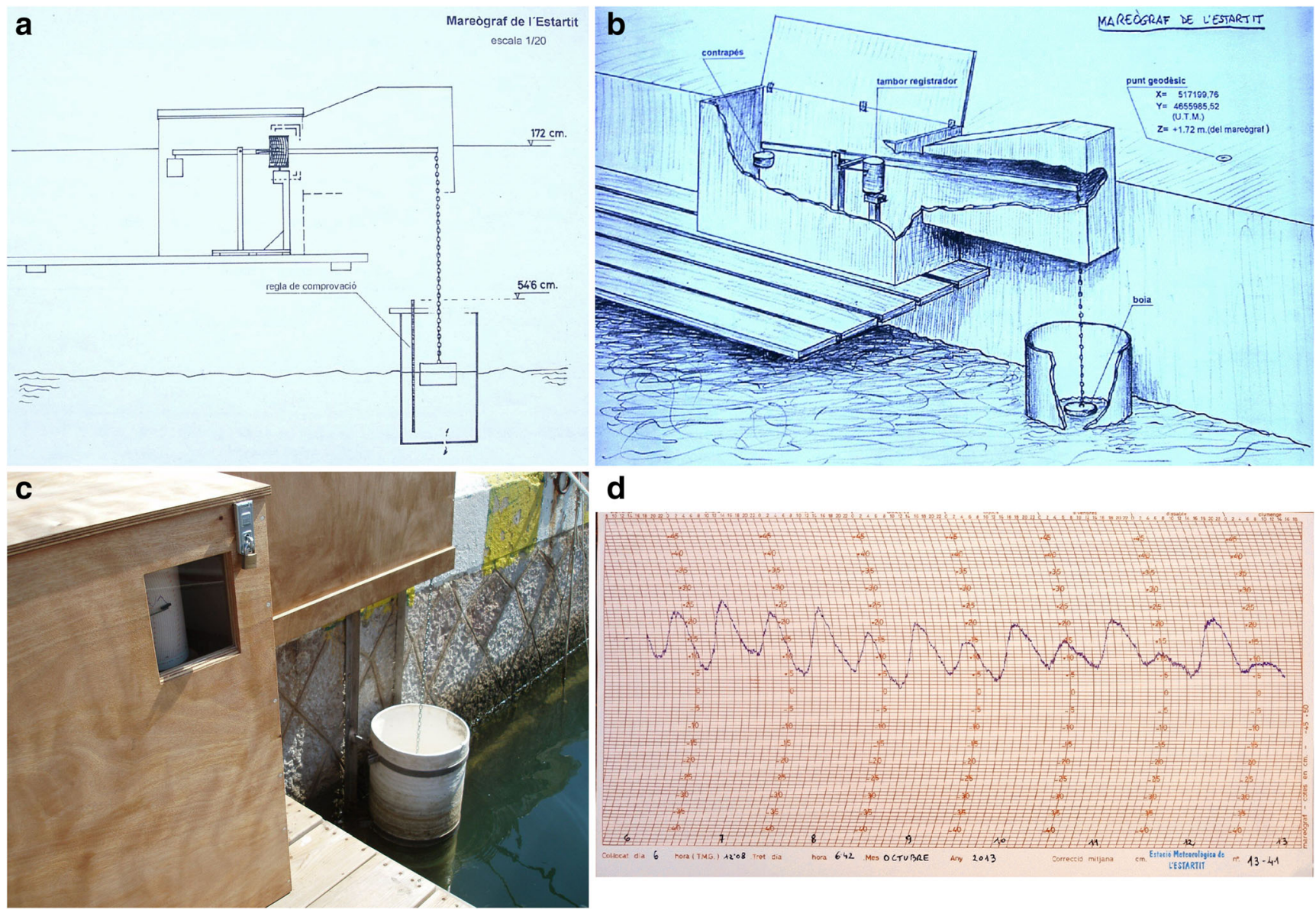

Fig. 3 Sea level gauge: a and $\mathbf{b}$ schematics of the instrument, $\mathbf{c}$ picture and $\mathbf{d}$ example of a weekly record

thermocline from early spring to late summer. Vertical exchanges of water during the stratified period are almost restricted to the surface mixed layer above the thermocline. Storms and surface cooling in autumn and early winter enlarge surface mixed layer to deeper layers to reach the bottom by the end of the year. According to the careful analyses done by Coma et al. (2009) using the present data set (up to 2006), two different criteria were used to characterize the stratification conditions at the observing point: mean monthly temperature at $20 \mathrm{~m}$ (S20T) higher than $18{ }^{\circ} \mathrm{C}$ and the difference

Table 1 Position, starting time and sampling frequency of the environmental parameters collected at L'Estartit, reported in this paper.

\begin{tabular}{|c|c|c|c|c|}
\hline Parameter & Location & Initial time $^{1}$ & Frequency & Accuracy \\
\hline Precipitation & $42^{\circ} 03^{\prime} \mathrm{N} 3^{\circ} 12^{\prime} \mathrm{E}$ & 1969 & Daily $^{2}$ & $0.1 \mathrm{~mm}$ \\
\hline Atmospheric pressure & $42^{\circ} 03^{\prime} \mathrm{N} 3^{\circ} 12^{\prime} \mathrm{E}$ & 1969 & 3 times/day $(08 \mathrm{~h}, 13 \mathrm{~h}, 18 \mathrm{~h})$ & $0.1 \mathrm{HPa}$ \\
\hline Relative cloudiness & $42^{\circ} 03^{\prime} \mathrm{N} 3^{\circ} 12^{\prime} \mathrm{E}$ & 1969 & 3 times/day & $<1 / 8$ \\
\hline Air temperature & $42^{\circ} 03^{\prime} \mathrm{N} 3^{\circ} 12^{\prime} \mathrm{E}$ & 1971 & Continuous & $<0.2^{\circ} \mathrm{C}$ \\
\hline Potential evaporation & $42^{\circ} 03^{\prime} \mathrm{N} 3^{\circ} 12^{\prime} \mathrm{E}$ & 1976 & Daily & $0.1 \mathrm{~mm}$ \\
\hline Relative humidity & $42^{\circ} 03^{\prime} \mathrm{N} 3^{\circ} 12^{\prime} \mathrm{E}$ & 1971 & 3 times/day & $0.2 \%$ \\
\hline Wind & $42^{\circ} 03^{\prime} \mathrm{N} 3^{\circ} 11^{\prime} \mathrm{E}$ & 1988 & Every $3 \mathrm{~h}$ & $2 \%$ \\
\hline Sea level & $42^{\circ} 03^{\prime} \mathrm{N} 3^{\circ} 12^{\prime} \mathrm{E}$ & 1990 & Continuous & $1 \mathrm{~cm}$ \\
\hline Sea temperature $\mathrm{at}^{3}: 0,5,20,35,50,65,80 \mathrm{~m}$ & $42^{\circ} 03^{\prime} \mathrm{N} 3^{\circ} 15^{\prime} \mathrm{E}$ & 1973 & > Weekly (60-100/year) & $<0.1^{\circ} \mathrm{C}$ \\
\hline CTD surveys & Various & 1995 & $\sim$ Monthly & $0.01{ }^{\circ} \mathrm{C}, 0.01 \mathrm{psu}, 0.1 \mathrm{ba}$ \\
\hline
\end{tabular}

${ }^{1}$ Starting in January if not otherwise indicated

${ }^{2}$ Frequency was improved to hourly data since 1986

${ }^{3}$ Levels marked in italics are those sampled at every visit, the rest are sampled with lower frequency 
between S20T and mean monthly temperatures at $80 \mathrm{~m}$ (S80T) is higher than $4.7^{\circ} \mathrm{C}$. It is assumed that in spring, when the $\mathrm{S} 20 \mathrm{~T}$ reaches $18{ }^{\circ} \mathrm{C}$, stratification is consolidated and cannot be reversed until the autumn cooling. Similarly, limited vertical water exchanges will be reflected when higher than a threshold temperature difference is between 20 and $80 \mathrm{~m}$. In the present paper, since there were almost no differences in the behaviour of these two criteria, we used only the first one for the duration of the stratified period, also referred to as summer conditions. The evolution of S20T-S80T will be used for climate trends.

Evaporation over the sea cannot be easily measured and, in many cases, especially in modelling, bulk formulae have been used to get reasonable estimates of the evaporation rates. These estimates are essentially based on the capacity of an air mass to absorb water vapour assuming that air in contact with the sea surface will get the same temperature as the sea surface and reach the water saturation (Jacobs 1942). Although our data sets would provide information to have estimates of the sea evaporation, they would not be as consistent as other data reported here, so we decided not to include them in the results and consider only the evolution of the conditions favourable to an effective evaporation. As observed by Sverdrup et al. (1942, p 117-119), sea surface temperature higher than air temperature will favour evaporation while in the opposite case it will be greatly limited. Accordingly, within the annual cycle, there is a period favourable to sea evaporation, when SST is higher than air temperature (AT). In this paper, we used the monthly AT-SST to estimate the evaporation favourable conditions.

To estimate the duration of annual periods for a given condition such as that favourable to evaporation or the abovementioned stratification, linear interpolation between monthly data is used, assuming that the actual monthly mean value corresponded to the mid-month day (14 to 15.5 according to the month). Trends for these periods are obtained by linear regression with the same treatment as monthly or seasonal data but with only 45 data points, one per year.

Heat content within the upper $80 \mathrm{~m}$ of the water column (not shown) can also be calculated using the sea temperatures obtained at surface, $20 \mathrm{~m}, 50 \mathrm{~m}$ and $80 \mathrm{~m}$, assuming these to be representative of temperatures at $0-10 \mathrm{~m}, 10-35 \mathrm{~m}$, $35-65 \mathrm{~m}$ and $65-80 \mathrm{~m}$, respectively.

\subsection{Satellite products}

Several satellite-based sea surface temperature (SST) analysis data sets were used for comparisons. These data sets are daily compositions of multiple satellite SST measurements of various horizontal resolutions ranging from 1 to $25 \mathrm{~km}$, and they differ in selection of the input data sets as well as in how the input data are interpolated on to a grid whose resolution also varies from 1 to $25 \mathrm{~km}$. They are the Multi-scale Ultra-high Resolution (MUR) analysis from NASA Jet Propulsion Laboratory (Chin et al. 2017), Italian Institute of Atmospheric Sciences and Climate Gruppo di Oceanografia da Satellite (GOS) Mediterranean analysis (Buongiorno Nardelli et al. 2013), the Canadian Meteorological Centre (CMC) analysis (Brasnett 2008), UK Met Office Operational Sea Surface Temperature and Sea Ice Analysis (OSTIA) (Donlon et al. 2012), and National Center for Environmental Information (NCEI) optimal interpolation analysis (Reynolds et al. 2007). All these data sets may be accessed through registration at the Physical Oceanography Distributed Active Archive Center (PO.DAAC) and use of the PO:DAAC drive at https:// podaac-tools.jpl.nasa.gov/drive/. For comparison, an SST time series coincident with the in situ counterpart is obtained from each of these analysis data sets by bilinear interpolation to the L'Estartit sampling location on the sampling dates. Since the earliest satellite SST measurements are from 1980s and some of the satellite analyses go back in time much less, we make comparison only for the recent years, from 2013 to 2018 .

\section{Results}

\subsection{Annual cycles}

The average annual cycle of air and SST (Fig. 4a) shows that from late winter-early spring to mid-summer, SST is lower than air temperature while during the rest of the year, the situation is reversed. The initial and ending days for the period when SST are colder than air temperature is presented in Fig. $4 \mathrm{~b}$ and the corresponding annual trend in Table 2. There is a successive advancement of the starting point of the period $(p<0.0001)$ while the delay in ending point is less significant ( $p<0.01$, i.e., still within the $99 \%$ of confidence). Such a behaviour has a relevant role in the air-sea interaction, in particular concerning sea water evaporation/condensation, and thus in the local water cycle.

The annual cycle of S20T is presented in Fig. 5a to indicate the initial and ending points of the stratified period. The evolution of these points is presented in Fig. 5b and the corresponding annual trends in Table 2. The evolution shows an enlargement of the period associated to both an advancement of the starting point and delay of the ending point. Although there are strong interannual differences in this process, from cold years when stratified period is short to hot waves with long periods of stratification, all these situations have significant biological implications that may affect local fisheries. 


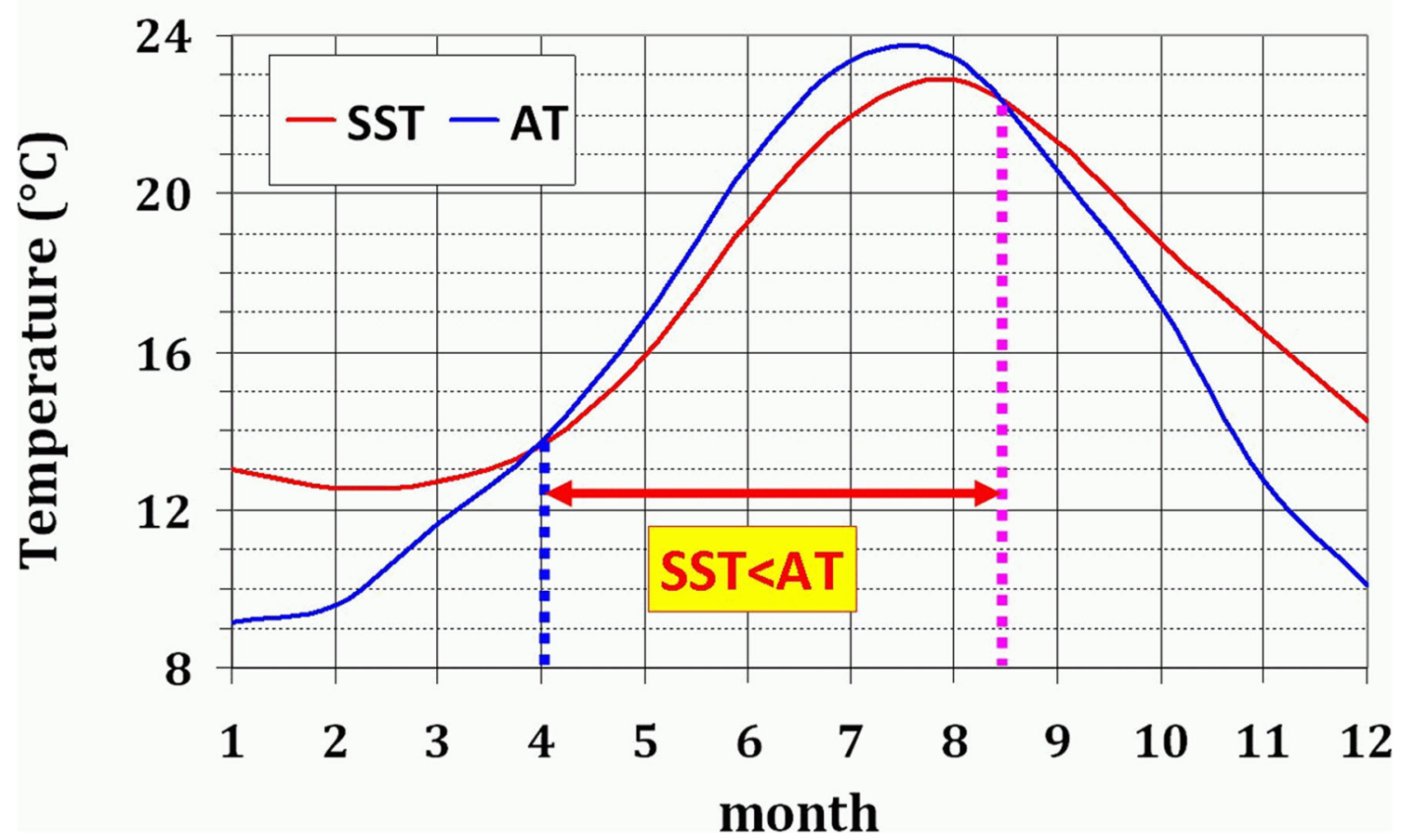

b Annual period with AT $>$ SST

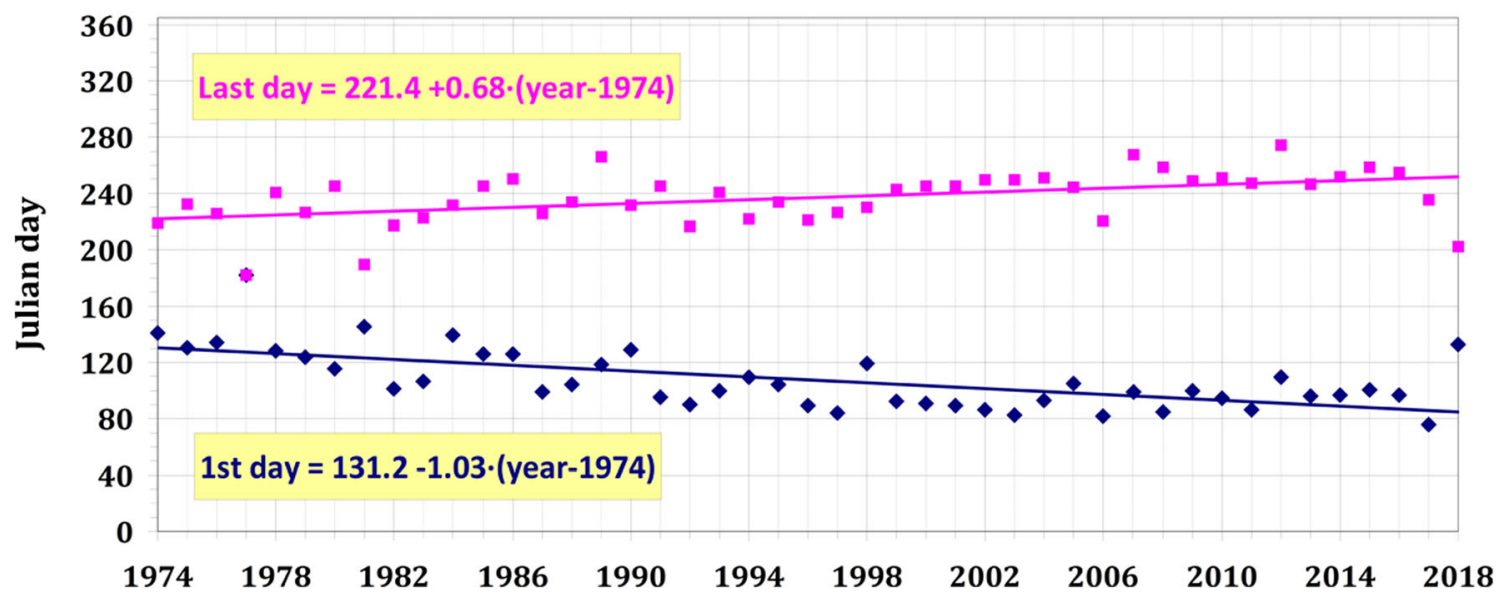

Fig. 4 a Mean annual cycle (1974-2018) of monthly air and sea surface temperature. The period when air temperature is higher than sea surface temperature is marked. b Time evolution of the period when air

\subsection{Monthly temperatures}

Monthly AT, SST and S80T temperature anomalies, with the respective linear trends are presented in Fig. 6. All the three sequences show a high interannual variability and upward linear increasing annual rates (Table 2). AT a warming trend higher than SST and S80T is increasing at a lower rate than at surface. Seasonal trends at surface show their maxima in spring $(p<0.0001)$ and a less temperature is higher than sea surface temperature. Blue points indicate the initial day of this period and pink points the end. Lines show the linear fitting marked and also less significant value $(p<0.01)$ in summer and autumn (Table 2).

Monthly temperature differences between air and sea surface (AT-SST) are presented in Fig. 7a. According to the trends shown above, there is a significant upward annual trend. Seasonal trends are lower or similar than the annual trend, except in spring where it is nearly twice the annual and more than three times the winter trend (Table 2). Monthly temperature differences between sea temperatures at 20 and $80 \mathrm{~m}$ (S20T- 
Table 2 Summary of annual (in bold) and seasonal linear trends of air and sea properties (in italics, if non-significant at $99 \%$ confidence), CI: limits of the $99 \%$ confidence interval if applicable, $p$ value upper bound for the trend (i.e. the maximum probability of observing such a trend only by chance is lower than this value. See section 3.1 for details)

\begin{tabular}{|c|c|c|c|}
\hline Property & Value per annum & CI $(99 \%) \pm$ & $p$ value \\
\hline Air temperature (AT) & $+0.0556{ }^{\circ} \mathrm{C}$ & $\pm \mathbf{0 . 0 1 2 7}$ & 0.000001 \\
\hline Winter & $+0.0356^{\circ} \mathrm{C}$ & \pm 0.0244 & 0.0005 \\
\hline Spring & $+0.0780^{\circ} \mathrm{C}$ & \pm 0.0186 & 0.000001 \\
\hline Summer & $+0.0551^{\circ} \mathrm{C}$ & \pm 0.0210 & 0.000001 \\
\hline Autumn & $+0.0536^{\circ} \mathrm{C}$ & \pm 0.0240 & 0.000001 \\
\hline Sea surface temperature (SST) & $+0.0316^{\circ} \mathrm{C}$ & $\pm \mathbf{0 . 0 0 9 9}$ & 0.000001 \\
\hline Winter & $+0.0238^{\circ} \mathrm{C}$ & \pm 0.0117 & 0.000002 \\
\hline Spring & $+0.0391{ }^{\circ} \mathrm{C}$ & \pm 0.0156 & 0.000001 \\
\hline Summer & $+0.0299{ }^{\circ} \mathrm{C}$ & \pm 0.0187 & 0.0001 \\
\hline Autumn & $+0.0337^{\circ} \mathrm{C}$ & \pm 0.0190 & 0.00005 \\
\hline Sea temperature at $80 \mathrm{~m}$ depth $(\mathrm{S} 80 \mathrm{~T})$ & $+0.0201{ }^{\circ} \mathrm{C}$ & \pm 0.0070 & 0.000001 \\
\hline Winter & $+0.0143{ }^{\circ} \mathrm{C}$ & \pm 0.0111 & 0.002 \\
\hline Spring & $+0.0227^{\circ} \mathrm{C}$ & \pm 0.0081 & 0.000001 \\
\hline Summer & $0.0115^{\circ} \mathrm{C}$ & \pm 0.0073 & 0.0002 \\
\hline Autumn & $+0.0320^{\circ} \mathrm{C}$ & \pm 0.0203 & 0.0002 \\
\hline $\mathrm{AT}-\mathrm{SST}$ & $+0.0240{ }^{\circ} \mathrm{C}$ & $\pm \mathbf{0 . 0 0 7 7}$ & 0.000001 \\
\hline Winter & $+0.0118^{\circ} \mathrm{C}$ & & 0.1 \\
\hline Spring & $+0.03899^{\circ} \mathrm{C}$ & \pm 0.0123 & 0.000001 \\
\hline Summer & $+0.0253{ }^{\circ} \mathrm{C}$ & \pm 0.0122 & 0.000001 \\
\hline Autumn & $+0.0199{ }^{\circ} \mathrm{C}$ & \pm 0.0181 & 0.005 \\
\hline Sea temperature at $20(\mathrm{~S} 20 \mathrm{~T})-\mathrm{S} 80 \mathrm{~T}$ & $+0.0098^{\circ} \mathrm{C}$ & $\pm \mathbf{0 . 0 0 5 7}$ & 0.00001 \\
\hline Winter & $+0.0065^{\circ} \mathrm{C}$ & \pm 0.0047 & 0.0005 \\
\hline Spring & $+0.0104{ }^{\circ} \mathrm{C}$ & \pm 0.0097 & 0.01 \\
\hline Summer & $+0.0197{ }^{\circ} \mathrm{C}$ & \pm 0.0157 & 0.002 \\
\hline Autumn & $+0.0025^{\circ} \mathrm{C}$ & & $>0.2$ \\
\hline Period of AT $>$ SST & +1.71 days & $\pm \mathbf{0 . 7 2}$ & 0.000002 \\
\hline Initial day & -1.03 days & \pm 0.52 & 0.000005 \\
\hline Final day & +0.68 days & \pm 0.52 & 0.002 \\
\hline Period of S20T $>18^{\circ} \mathrm{C}$ & +0.87 days & $\pm \mathbf{0 . 5 7}$ & 0.0001 \\
\hline Initial day & -0.49 days & \pm 0.31 & 0.0002 \\
\hline Final day & +0.39 days & \pm 0.38 & 0.01 \\
\hline Mean sea level & $+3.304 \mathrm{~mm}$ & \pm 0.890 & 0.000001 \\
\hline Annual precipitation & $-0.67 \mathrm{~mm}$ & & $>0.2$ \\
\hline Winter & $-0.03 \mathrm{~mm}$ & & $>0.2$ \\
\hline Spring & $-1.34 \mathrm{~mm}$ & & 0.15 \\
\hline Summer & $-0.08 \mathrm{~mm}$ & & $>0.2$ \\
\hline Autumn & $+0.78 \mathrm{~mm}$ & & $>0.2$ \\
\hline
\end{tabular}

S80T) are presented in Fig. 7b. In this case, the summer seasonal trend is about twice the annual trend - other seasons show lower or non-significant trends (Table 2).

\subsection{Monthly sea level}

The amplitude of the astronomical tide at L'Estartit is lower than $20 \mathrm{~cm}$. Monthly averaged mean sea level as well as monthly maximum and minimum anomalies display a mean positive trend of more than $3 \mathrm{~cm} /$ decade (Fig. 8; Table 2). Sea level records reflect some episodic seiches with high-frequency oscillations (1/600) and tide amplitudes reaching $100 \mathrm{~cm}$, associated with shifts $(>2 \mathrm{mb} / \mathrm{h})$ and rapid oscillations of the atmospheric pressure (Fig. 9). The positive trend in sea level would be at least partially compatible with the net heat gain shown above. 
a annual cycles at different depths

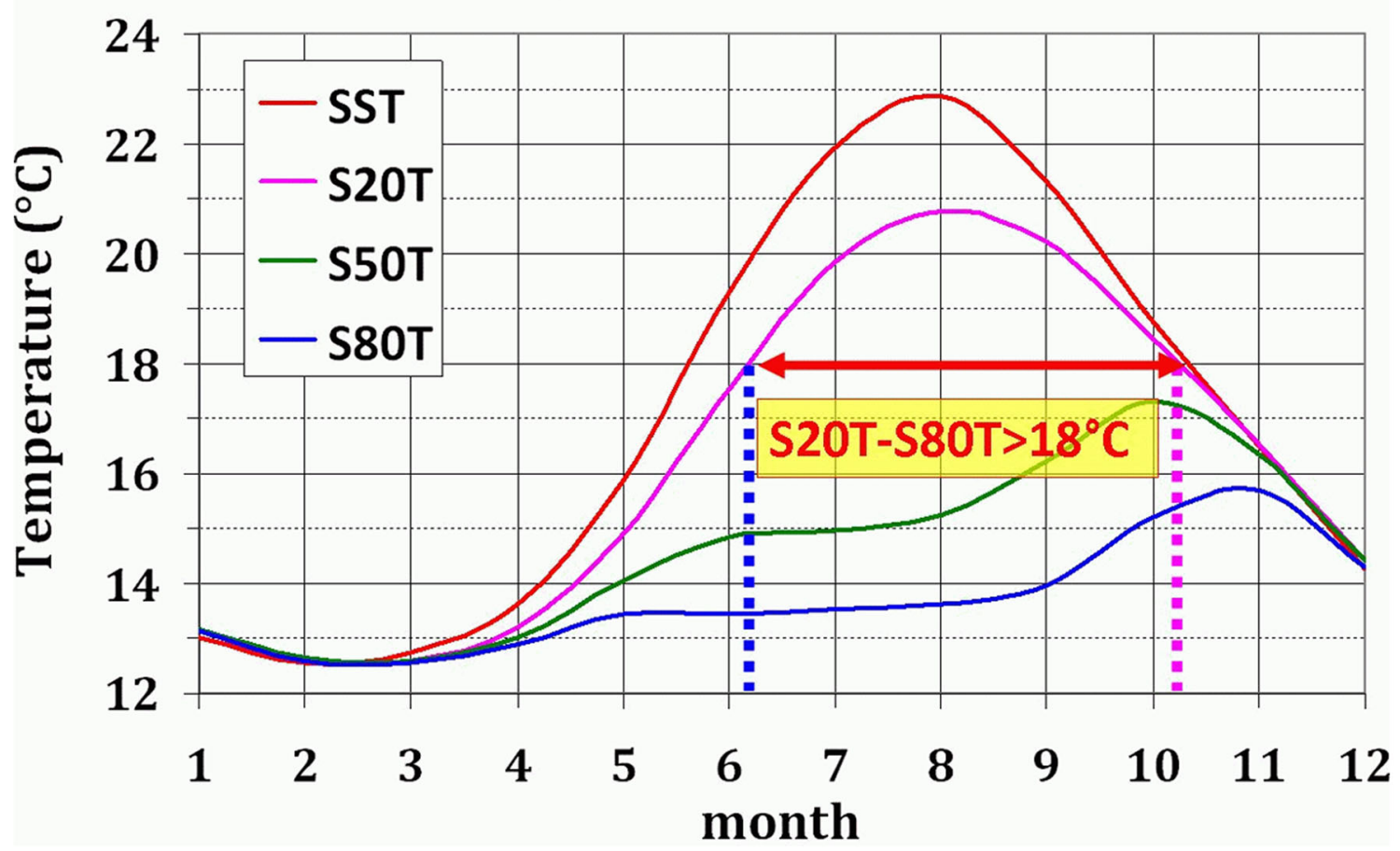

b

Annual period with $S 20 \mathrm{~T}>18^{\circ} \mathrm{C}$

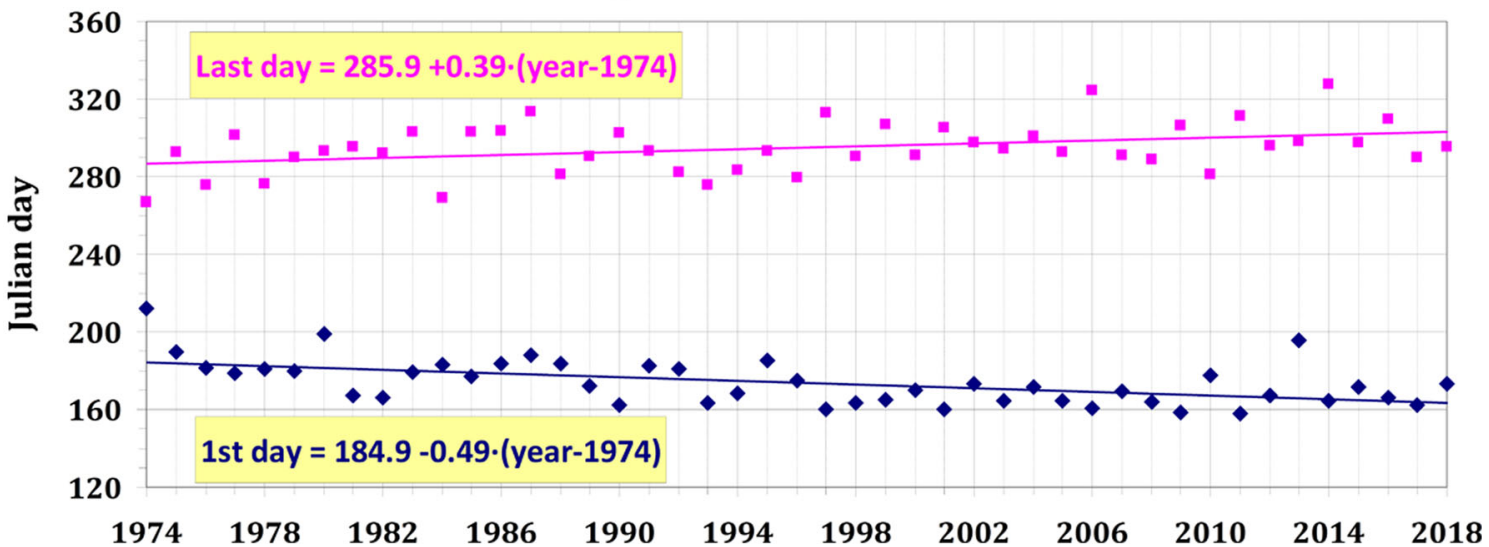

Fig. 5 a Mean annual cycle (1974-2018) of sea temperature at the four sampled levels. The period when temperature at $20 \mathrm{~m}$ is higher than $18^{\circ}$ is marked. b Time evolution of the period when sea temperature at $20 \mathrm{~m}$ is

higher than $18{ }^{\circ} \mathrm{C}$. Blue points indicate the initial day of this period and pink points the end. Lines show the linear fitting

\subsection{Local precipitation}

Annual and Spring accumulated precipitation are presented in Fig. 10, and the corresponding trends appear in Table 2. Although anyone of these trends is not statistically significant (only in spring has a relatively low $p$ value), they are included for its descriptive interest. In particular, it is worth to note that almost all the annual decay corresponds to the spring season. This trend is also confirmed by the decrease in spring precipitation of nearly a $30 \%$ by comparing the average from 1974 to 1983 and 2009-2018. It also can be related to the decay in sea evaporation in the season suggested by the trend to early dates of starting the period in which sea surface temperature is lower than air temperature (Fig. 4; Table 2).

\section{Comparisons}

\subsection{In situ data vs. current satellite products}

The L'Estartit sea surface temperature (SST) time series agrees quite well with the SST time series derived from the 


\section{a}

L'Estartit: Monthly AT anomaly $\left({ }^{\circ} \mathrm{C}\right)$
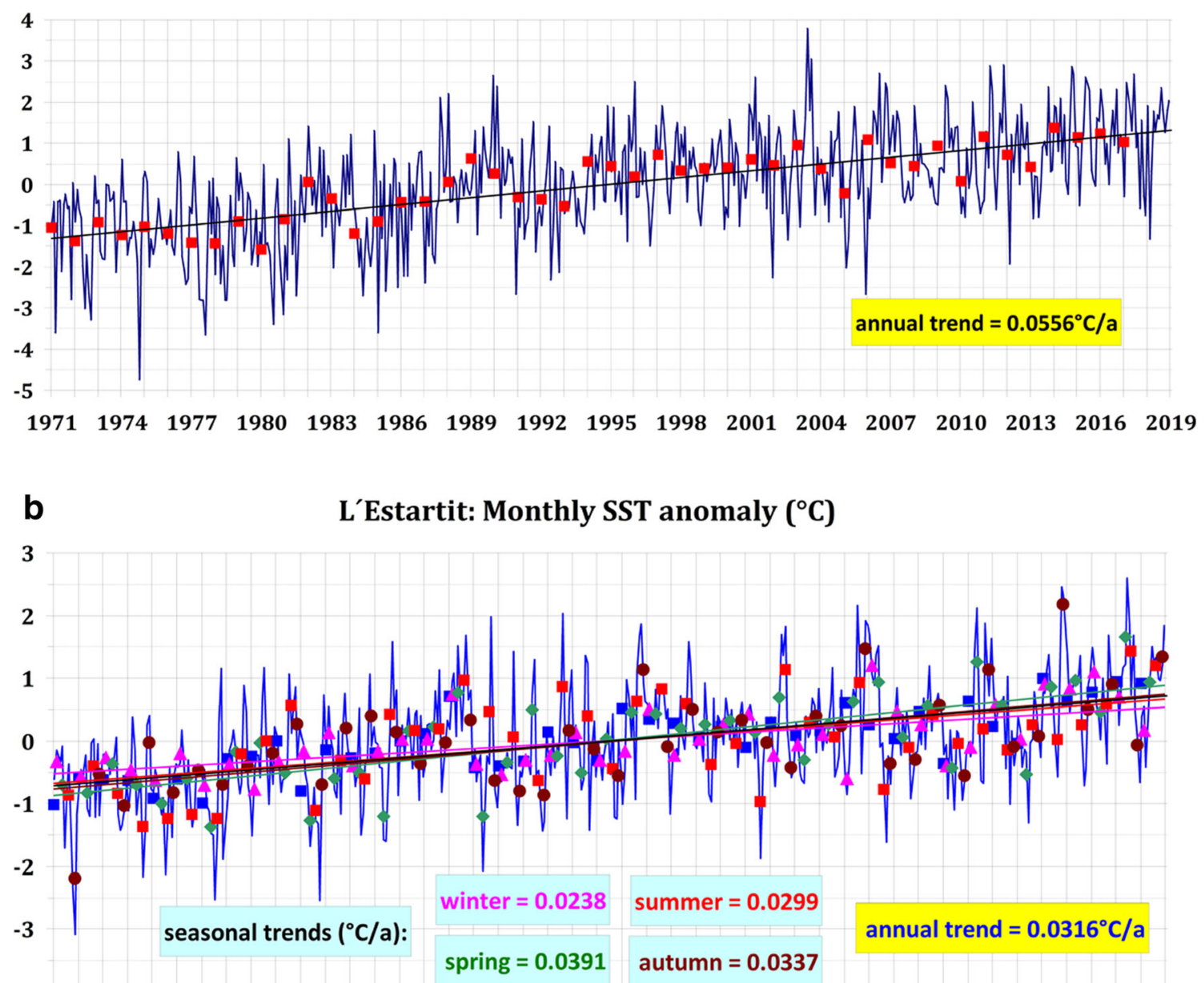

$-4$

1974197719801983198619891992199519982001200420072010201320162019

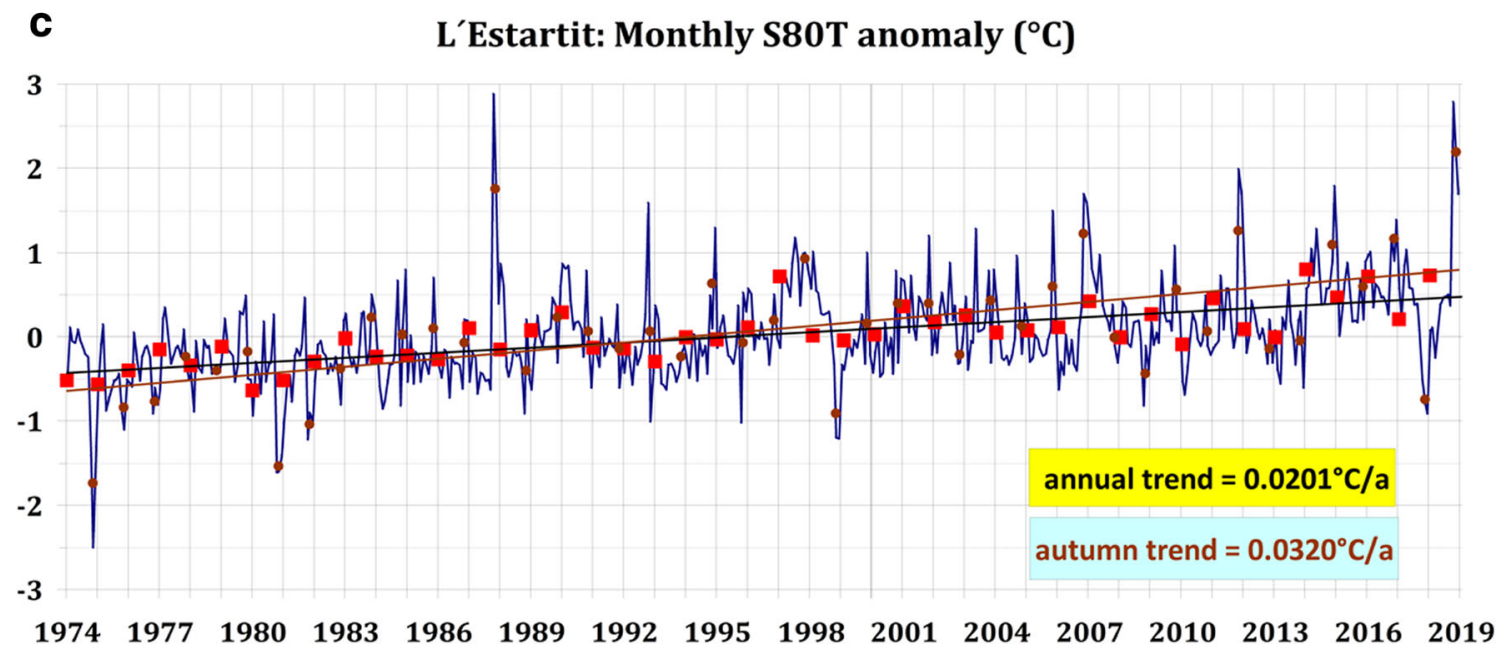

Fig. 6 a Time series of monthly air temperature anomalies (line), annual mean (squares) and linear trend. b Time series of monthly sea surface temperature anomalies (line), annual mean (blue squares), winter (pink triangles), spring (small green squares), summer (red squares) and autumn

(brown circles). Seasonal trend lines are coloured according to the symbols. c Time series of monthly sea temperature anomalies at $80 \mathrm{~m}$ (line), annual mean (squares), autumn values (brown circles) and their linear trends 
a

\section{L'Estartit: Monthly AT - SST anomalies $\left({ }^{\circ} \mathrm{C}\right)$}

4

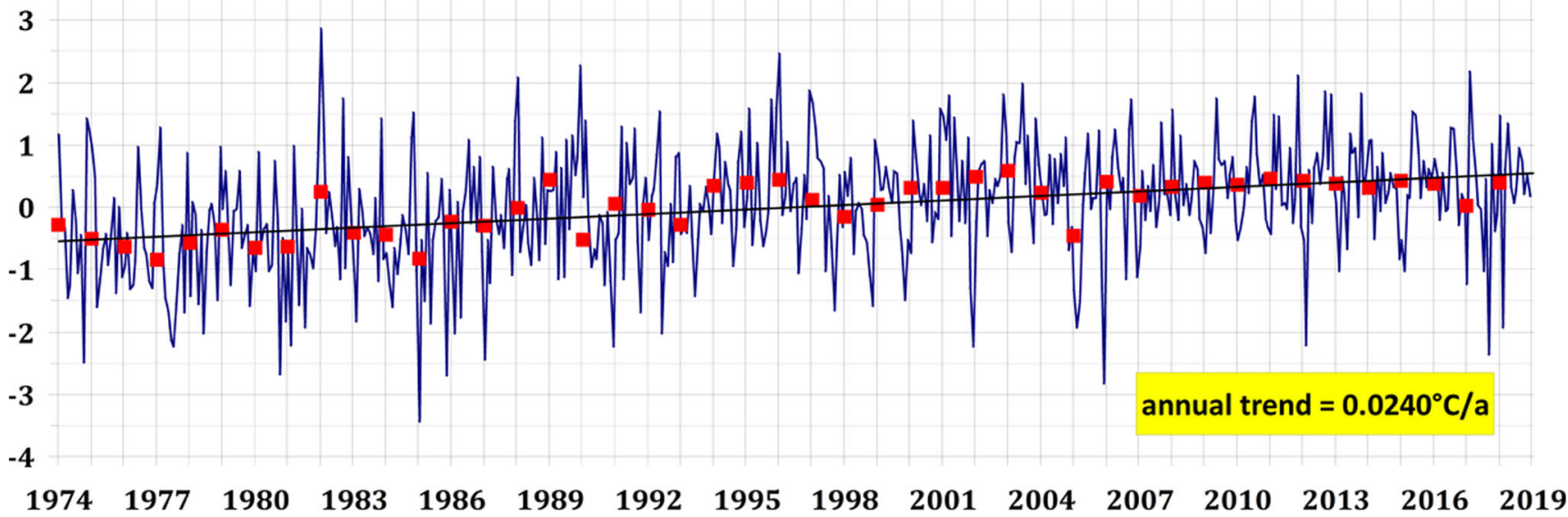

b

L'Estartit: Monthly S20T-S80T anomalies $\left({ }^{\circ} \mathrm{C}\right)$

3

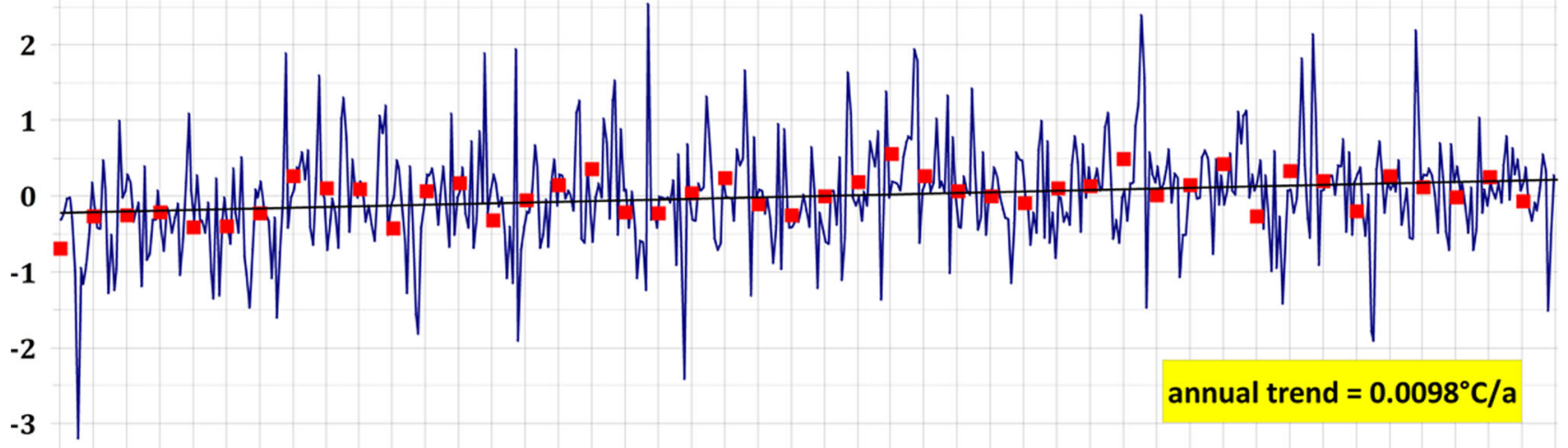

$-4$

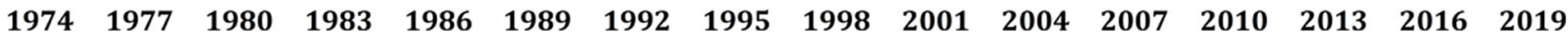

Fig. 7 a Time series of monthly anomalies of the difference between air temperature and sea surface temperature (line), annual mean (squares) and linear trend. b Time series of monthly anomalies of the difference between sea temperature at 20 and $80 \mathrm{~m}$ (line), annual mean (squares) and linear trend

Fig. 8 Time series of monthly sea level anomalies with trend lines for mean, maximum and minimum values
L'Estartit: Mean Sea-Level anomaly $(\mathrm{cm})$

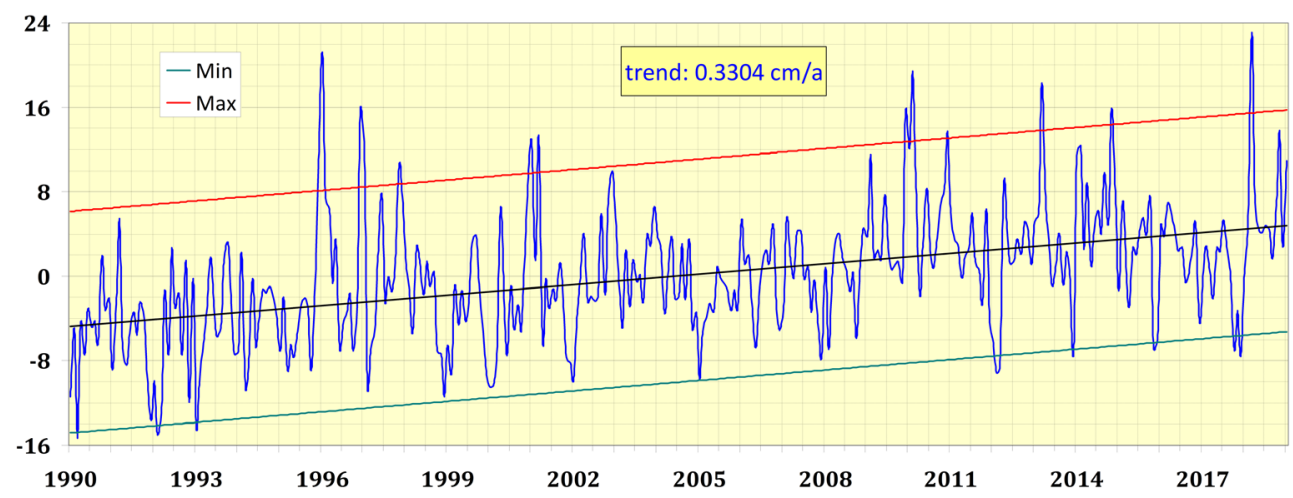




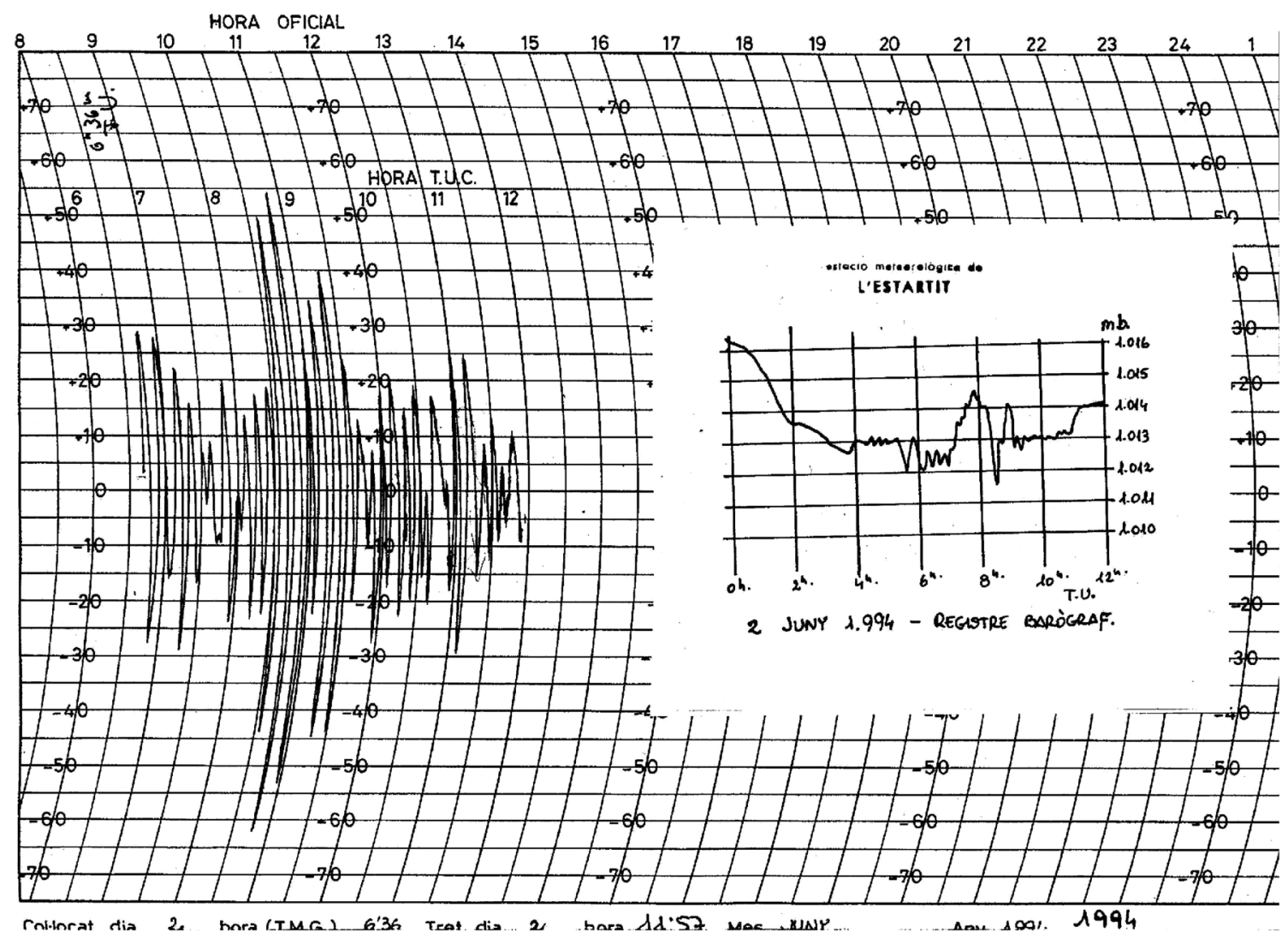

Fig. 9 Example of high-frequency sea level oscillations (seixes) recorded on 2 June 1994, starting at 06:30 GMT. Enclosed is the atmospheric pressure record of the first $12 \mathrm{~h}$ of the same day

various satellite-based data sets (Fig. 11), with an RMS difference of consistently just over $0.5^{\circ} \mathrm{C}$ (Table 3 and Table 4). This is comparable with the typical minimum uncertainty in satellite SST measurement of $0.3-0.5^{\circ} \mathrm{C}$. The satellite SST is cooler than the L'Estartit SST by 0.1 to $0.2^{\circ} \mathrm{C}$ on average. A potential cause for this bias is the diurnal warming of sea temperature: while the satellite data sets are aiming to report the pre-dawn temperature, the L'Estartit measurements are performed mostly in the late morning to noon. We note that the feature resolution (smoothness of the SST field) of the satellite data sets used here varies vastly from around 1 up to
$100 \mathrm{~km}$, with the OSTIA and NCEI data sets having a similar feature resolution of around $100 \mathrm{~km}$ despite having fairly different grid spacing (Reynolds and Chelton 2010; Chin et al. 2017). The comparison statistics (RMS and bias) are remarkably consistent across feature resolutions up to $25 \mathrm{~km}$, and degrades only by 0.1 to $0.2{ }^{\circ} \mathrm{C}$ for the OSTIA and NCEI data sets. This indicates that the temporal variability of the L'Estartit time series is representative of the areal average SST from the surrounding sea.

The good statistical comparison of sea surface temperature values (Table 3 and Table 4) and trends (Table 5) obtained
Fig. 10 Time series of annual (blue) and spring (red) precipitation and its corresponding linear trend (significant at 85\%)

\section{L'Estartit: Annual and Spring precipitation (mm)}

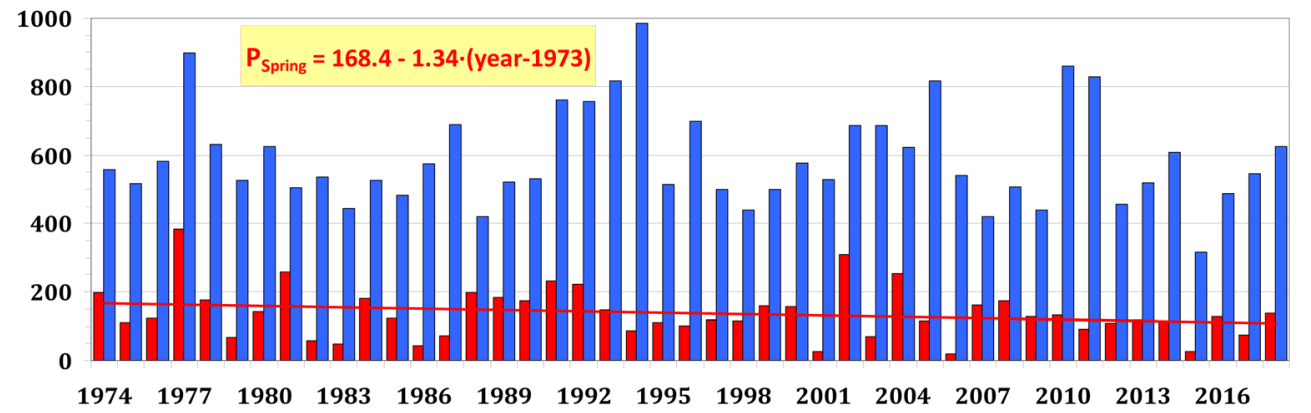


Fig. 11 Time series of sea surface temperature recorded from L'Estartit site (J. Pascual, in clay) and from the Multi-scale Ultrahigh Resolution (MUR, in grey) analysis. a 2002-2018. b Zoom from 2016 to 2018 a

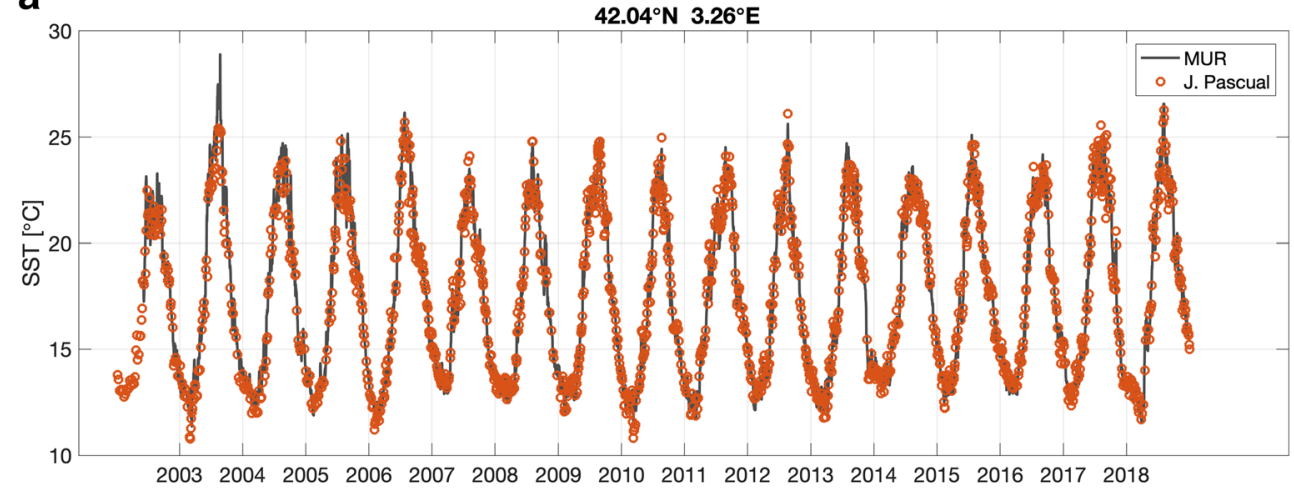

b

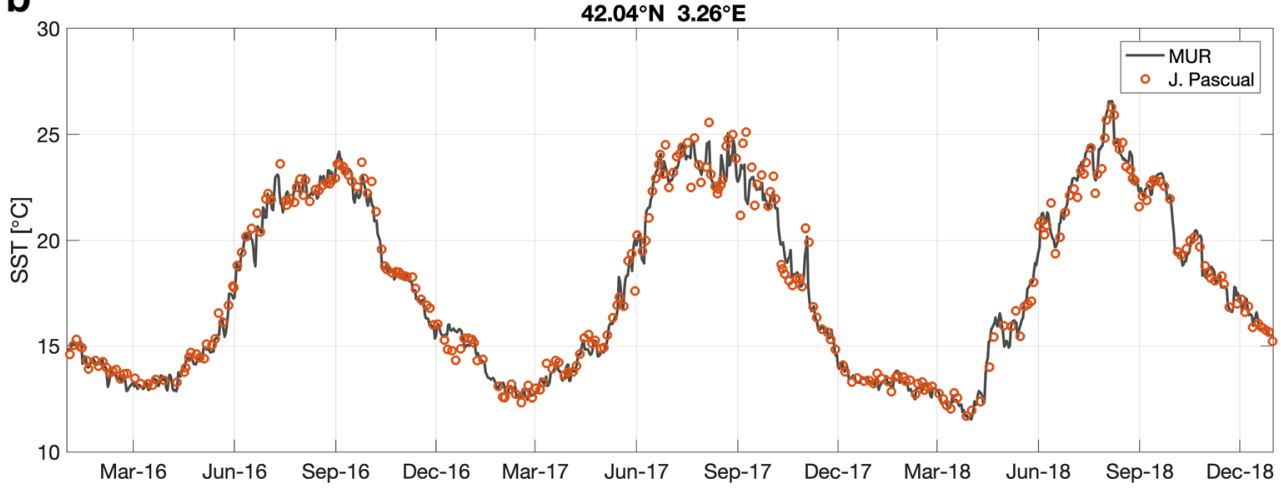

from L'Estartit data set and from available satellite products confirms that the reported sea surface temperature trends are robust. Additionally, their good agreement for such a longterm (more than 5 consecutive years) is a first step towards the cross-validation of these products. That opportunity to validate the multi-decadal trends that can now be observed in satellite data gives more confidence to use these data to model and/or parameterize time changes in oceanic states (which have often assumed to be recurring in order to develop theories, e.g. for spatial patterns).

\subsection{Comparison with previous and other estimates of climate trends}

Most of the articles published within the two last decades show the Western Mediterranean has increased in temperature and salinity during the twentieth century. Most of these articles, however, focused on the intermediate and deep layers; works dealing with changes in the upper layers and shallow waters remain scarce. Vargas-Yáñez et al. (2005) analysed coastal data obtained at several fixed stations and detected strong warming trends in the near surface waters, usually ranging from 0.02 to $0.05{ }^{\circ} \mathrm{C} /$ year, up to almost $0.1{ }^{\circ} \mathrm{C}$ /year (in the Ligurian sea) during the 1990s. These results (of almost one order of magnitude higher than those found at intermediate and deep waters) contrasted with those from Krahmann and Schott (1998) and Sparnocchia et al. (1994) that found no significant changes in the temperature evolution of the upper layer in the Western Mediterranean since the mid-1970s. More recent works, that included data from satellite infrared data, evidenced the warming of the surface layer, both in the Western and Eastern Mediterranean since the mid-1980s to the first decade of the twenty-first century (Skliris et al. 2012; Nykjaer 2009). The trend estimates in these two papers are close to those obtained from our station. Similarly, Rixen et al. (2005), using data from the MEDATLAS database, found positive trends of about $0.02{ }^{\circ} \mathrm{C} /$ year in the upper layer temperatures since mid-1980s, after an almost steady (zero trend) situation in the previous 30 years. Near the coast in

Table 3 Pair-wise comparison to L'Estartit time series at $42.0500^{\circ} \mathrm{N}$, $3.2542^{\circ} \mathrm{E}$

\begin{tabular}{llllll}
\hline Product & RMS & Bias & Scatter & Max & Min \\
\hline MUR 1 km & 0.60 & -0.04 & 0.60 & 4.06 & -3.32 \\
MUR 25 km & 0.61 & 0.01 & 0.61 & 4.01 & -3.34 \\
GOS 1 km & 0.51 & -0.16 & 0.49 & 2.26 & -1.93 \\
GOS 6 km & 0.53 & -0.22 & 0.48 & 2.30 & -2.03 \\
CMC 10 km & 0.64 & -0.20 & 0.61 & 1.97 & -2.73 \\
CMC 20 km & 0.55 & -0.07 & 0.55 & 3.79 & -2.15 \\
CMC 10-20 km & 0.57 & -0.07 & 0.56 & 3.79 & -2.73 \\
OSTIA 5 km & 0.62 & -0.20 & 0.59 & 2.43 & -2.87 \\
NCEI 25 km & 0.75 & -0.25 & 0.71 & 2.50 & -4.24 \\
\hline
\end{tabular}


Table 4 Pair-wise comparison to L'Estartit time series at $42.0500^{\circ} \mathrm{N}$, $3.2542^{\circ} \mathrm{E}$, but using only the common time interval from $27 / 04 / 2013$ to $31 / 12 / 2018$

\begin{tabular}{lccccc}
\hline Product & RMS & Bias & Scatter & Max & Min \\
\hline MUR 1 km & 0.54 & -0.14 & 0.52 & 2.16 & -3.32 \\
MUR 25 km & 0.55 & -0.01 & 0.54 & 2.20 & -3.34 \\
GOS 1 km & 0.53 & -0.14 & 0.51 & 2.26 & -1.93 \\
GOS 6 km & 0.54 & -0.20 & 0.50 & 2.30 & -2.03 \\
CMC 10-20 km & 0.56 & -0.16 & 0.54 & 1.97 & -2.73 \\
OSTIA 5 km & 0.62 & -0.20 & 0.59 & 2.43 & -2.87 \\
NCEI 25 km & 0.79 & -0.32 & 0.72 & 2.50 & -4.24 \\
\hline
\end{tabular}

the western side of the NW Mediterranean (where L'Estartit station is located), SST showed an average increase of nearly $0.7^{\circ} \mathrm{C}$ from 1960 to 2000 .

Vargas Yáñez et al. $(2009,2010)$ attempted to estimate the evolution of air and sea temperatures during the whole twentieth century, up to 2008 , in the Spanish waters of the Western Mediterranean. The authors merged the information from MEDATLAS with some of the more recent time series at fixed stations (RADMED) in the region. The estimates for the whole period and the whole area showed a non-significant trend for the upper layer of sea temperature of $0.0038 \pm$ $0.0032^{\circ} \mathrm{C} /$ year (partially due to the many gaps in the available series) and a significant trend of $0.0074 \pm 0.0013{ }^{\circ} \mathrm{C}$ for the air temperature. The evolution, however, showed an acceleration of the warming trends since around 1975 (from when data started to be more abundant although many locations still presented gaps). Trends similar to ours were only detected in the Balearic Sea, while much lower trends were found in the rest of NW Mediterranean areas. These analyses were updated in Vargas-Yáñez et al. (2017), and described the results for the period 1943-2015 in four separate areas, from the Alboran Sea to near the Gulf of Lions. Again, the upper layer temperatures did not show any significant trend, but while in the Alboran and Balearic areas, these trends were slightly negative, in the SE of Spain and in the north trends were slightly positive.

The Copernicus Marine Environment Monitoring Service (CMEMS) provided annual reports of the state of the global

Table 5 Sea surface temperature annual trends from L'Estartit time series at $42.0500^{\circ}$ $\mathrm{N}, 3.2542^{\circ} \mathrm{E}$, using only the common time interval from $27 / 04 / 2013$ to $31 / 12 / 2018$

\begin{tabular}{ll}
\hline Product & Trend $\left({ }^{\circ} \mathrm{C} /\right.$ year $)$ \\
\hline L'Estartit & 0.0922 \\
MUR $1 \mathrm{~km}$ & 0.0611 \\
GOS $1 \mathrm{~km}$ & 0.0895 \\
GOS $6 \mathrm{~km}$ & 0.0861 \\
CMC $10-20 \mathrm{~km}$ & 0.0840 \\
OSTIA $5 \mathrm{~km}$ & 0.0609 \\
NCEI $25 \mathrm{~km}$ & 0.0301 \\
\hline
\end{tabular}

ocean and European regional seas based on all the available observations from 1993. In the 2016 report (von Schuckmann et al. 2016), the observed 1993-2015 SST trends for the whole ocean indicate a global increase of $0.016 \pm 0.002{ }^{\circ} \mathrm{C} /$ year (99\% confidence interval), that was quite sensitive to the particular strong increase in SST during the 2015 El Niño event. The Arctic region also showed a high SST increase during 2015 while this signal was much weaker in the North Atlantic. Within the European regional seas, the Mediterranean (including the Black sea) is where trends are the highest $\left(0.039 \pm 0.009^{\circ} \mathrm{C}\right.$ /year (95\% confidence interval). However, the Western Mediterranean basin presented lower trends, in good agreement with other observations (e.g. Vargas-Yáñez et al. 2009 and 2010). Again, the relative maxima of the NW basin appeared in open sea while at the coastal zone, including L'Estartit, remained within $0.02-0.03{ }^{\circ} \mathrm{C} /$ year. The CMEMS paper also mentioned that trends for subsurface layers down to $100 \mathrm{~m}$ are dependent on SST. For that reason, there is no information about the evolution at $80 \mathrm{~m}$. The update of the CMEMS report for 2018 (von Schuckmann et al. 2018) enlarged the length of the time series to 2016 and obtained a slightly higher trend for SST with reduced uncertainty $0.040 \pm 0.004^{\circ} \mathrm{C} /$ year. This may be attributed to the increase of the time series and the similarly high temperatures in the last years of the series.

In terms of sea level rise, despite the global increasing trend, sea level in the Mediterranean sea has been decreasing from the $1960 \mathrm{~s}$ to the $1990 \mathrm{~s}$, at an average rate of -0.5 to $1 \mathrm{~mm} /$ year, reaching rates as low as $-1.3 \mathrm{~mm} /$ year in some locations (Marcos and Tsimplis 2008). Such negative trend was attributed to an increase of the atmospheric pressure in the Mediterranean sea region, associated to the positive phase of the North Atlantic Oscillation (Gomis et al. 2008). Although Tsimplis and Baker (2000) suggested the increase would be associated to the increasing salinities of the sea during that period, Jordà and Gomis (2013) demonstrated that the influence of the reported changes in salinity was only residual. Since the mid-1990s, the atmospheric pressure recovered to its normal values for the Mediterranean region and the sea level started to rise at trends higher than $2 \mathrm{~mm} /$ year, reaching up to $10 \mathrm{~mm} /$ year (Criado-Aldeanueva et al. 2008; Gomis et al. 2008). Marcos et al. (2016), using satellite altimetry data, estimated an average increase in absolute (geocentric) sea level of $2.6 \pm 0.2 \mathrm{~mm} /$ year for the period 1993-2015.

The CMEMS report (von Schuckmann et al. 2016) estimated the sea level rising trend for 1993-2015 in the whole Mediterranean was $2.9 \pm 0.9 \mathrm{~mm} /$ year $(95 \%$ confidence interval), of which about one half corresponded to the thermosteric component. This figure is very similar to ours (Table 2). Interestingly, the whole-Mediterranean time series of sea level anomalies reproduced most of the peaks observed in our time series (Fig. 8) - namely in 1996, 1997, 2010 and 2013, but not 
that of 2000 which apparently appears 1 year later. The update of the CMEMS report for 2018 (von Schuckmann et al., 2018) that included one more year (2016) slightly reduced the previous estimate for the whole Mediterranean to $2.7 \pm 0.9 \mathrm{~mm} /$ year, as for other regional seas. The estimate for L'Estartit zone lies within 2.5 and $3.5 \mathrm{~mm} /$ year, in good agreement with CMEMS.

In terms of specific aspects of the annual cycle, such as the seasonal distribution of trends, the evolution of the difference between sea surface and air temperatures or stratification periods dealt in our paper, we hardly find any paper that specifically addressed these aspects in the Mediterranean, with the exception of those that used this set of data (e.g. Coma et al. 2009). Only scattered references to some of these subjects in the above-mentioned papers. In particular, it is worth to mention that in Skliris et al. (2012) seasonal trends were estimated for the Western, Eastern and the whole Mediterranean sea. In the Western Mediterranean, these trends were found to be much higher and significant in spring and summer than it was found in our series. The same paper also highlights the role of the latent heat exchanges as the dominant factor among the drivers of seasonality and long-term trends. In particular, they found that the temperature difference between air and sea surface is very well correlated with the latent heat exchanges, whose annual maximum falls in winter, as widely assumed. The relation of these temperature differences with latent heat exchanges, hence with evaporation, is a good support for our hypothesis. In particular, the decrease in spring evaporation may be related to the decrease in local precipitation during this season. Although we did not find any paper that highlighted this relation, many papers on Mediterranean climate (e.g. De Luis et al. 2009, 2010) show a decreasing trend in annual precipitation in the Western Mediterranean region that is more larger in spring.

Specific events such as the heat waves of summer 2003 and 2006 have been clearly reflected in the series and, although it is a shallow coastal station, the mild to very mild 1990, 2014, 2016 and 2017 winters as well as the exceptional heat loss in the 2004-2005 winter. While this extreme heat loss conducted to an unprecedent volume of dense water formation in the Western Mediterranean (Canals et al. 2006; Font et al. 2007), the previously mentioned mild winters only produced small amounts of water not dense enough to get the deep layers (Mertens and Schott, 1998; Schoreder et al. 2017).

Discrepancies among results reported above, as well as with ours, can be attributed to different factors, including uncertainties resulting from merging data from wide areas, the use of different methodologies to calculate the trends and the collection of data from different seasons. Last but not least, the high variability in the upper ocean layer introduces large standard deviations in data. The good statistical comparison of sea surface temperature values and trends obtained from L'Estartit data set and from available satellite products is encouraging.

\section{Conclusions}

The Mediterranean Sea is a recognized hot-spot for future climate changes, due to its characteristics of a miniature ocean, since most oceanographic processes of the global ocean (with the exception of sea ice formation processes) occur in it. More importantly, its relatively small size makes it more accessible to monitoring than other regions of the world. According to its geographic position in mid latitudes, the Mediterranean is subjected to a marked seasonality that essentially affects heat exchanges with the atmosphere and ocean stratification. The set of observations presented in this contribution, not yet completely digitalized, constitute a unique reference document of the evolution of a Mediterranean coastal environment for about half a century. Among other uses, it permits one to derive trends for local climate evolution, from surface to stratification of the upper ocean. These trends can then be contrasted with those currently obtained through big data processes (satellite observations and numerical models). During the last years, the dataset has been used in many scientific papers related to climate research and to document extreme events such as cold or heat waves, storms and their consequences on neritic ecosystems. Robust estimates of annual trends of sea temperature from SST $\left(0.03^{\circ} \mathrm{C} /\right.$ year $), \mathrm{S} 80 \mathrm{~T}$ $\left(0.02^{\circ} \mathrm{C} /\right.$ year $), \operatorname{AT}\left(0.05^{\circ} \mathrm{C} /\right.$ year $)$ and sea level $(3.1 \mathrm{~mm} /$ year $)$ are presented. Seasonal trends and other properties related to the seasonal cycle are also presented, some of them for the first time. A careful inspection and comparisons among annual and seasonal trends highlight the relative importance of seasonal processes such the thermocline formation or destruction and conditions for air/sea heat and mass exchanges. For instance, a separation among impacts of climate evolution according to the seasons has been useful to explain several ecological impacts at a local scale. It can also be to assign climate change impacts to processes acting at different seasons that can be masked if only annual trends are taking into account. Finally, the results can be used as reference for other Mediterranean areas. Some relevant results associated to the annual cycles are the stretching of the period of positive difference among air and sea surface temperature, that shows an increasing trend of nearly 2 days/year. Such a trend may partially explain a $30 \%$ decrease (although not significant) of coastal precipitation in spring. The present contribution also highlights the potential of this coastal dataset for climate evolution studies and as ground truth for sea surface temperature (SST) satellite estimations. Although there have been comparisons with ARGO, etc., they have been over very limited periods of time. For instance, the comparison presented here extended along more than 16 consecutive years (Fig. 11) and it 
is up to our knowledge the longest ever done. The good statistical agreement between on-site SST measurements and SST obtained from satellite observations confirms the reported positive trends are robust. In views of the results presented here, we propose L'Estartit observational site should become a long-term ground truth for satellite observations and a regional monitoring site for climate change.

Acknowledgements The authors acknowledge technical support from the Institut de Ciències del Mar (ICM/CSIC) to maintain the time series of L'Estartit. MF acknowledges support from the National Aeronautics and Space Administration (NASA) through grant number NNX15AG42G. The work by TMC and JV was performed at the Jet Propulsion Laboratory, California Institute of Technology, under contract with the NASA. The authors also thank the always warm atmosphere found in the Liège Colloquium and the suggestions received from the participants. The advice from the Editor and the reviews from three anonymous referees have greatly contributed to improve the original manuscript to reach the final version of this paper. The help of Dr. C. Behrens from PANGAEA was crucial to facilitate data publication in that repository.

Open Access This article is distributed under the terms of the Creative Commons Attribution 4.0 International License (http:// creativecommons.org/licenses/by/4.0/), which permits unrestricted use, distribution, and reproduction in any medium, provided you give appropriate credit to the original author(s) and the source, provide a link to the Creative Commons license, and indicate if changes were made.

\section{References}

Bograd SJ, Checkley DA Jr, Wooster WS (2003) CalCOFI: a half century of physical, chemical, and biological research in the California Current System. Deep-sea Res Part II-Topical Studies in Oceanography 50:2349-2353. https://doi.org/10.1016/S09670645(03)00122-X

Bougis $\mathrm{P}$, Carré C (1960) Conditions hydrologiques à Villefranche sur Mer pendant les années 1957 et 1958. Cahiers Océanographiques 12(6):392-408

Brasnett B (2008) The impact of satellite retrievals in a global seasurface-temperature analysis. QJR Meteorol Soc 134:1745-1760. https://doi.org/10.1002/qj.319

Bryden HL, Longworth HR, Cunningham SA (2005) Slowing of the Atlantic meridional overturning circulation at $25^{\circ} \mathrm{N}$. Nature 438: 655-657. https://doi.org/10.1038/nature04385

Buongiorno-Nardelli B, Tronconi C, Pisano A, Santoleri R (2013) High and ultra-high resolution processing of satellite sea surface temperature data over southern European seas in the framework of MyOcean project. Remote Sens Environ 129(1-16):1-16

Canals M, Puig P, Durrieu de Madron X, Heussner S, Palanques A, Fabres J (2006) Flushing submarine canyons. Nature 444:354-357

Chin TM, Vazquez-Cuervo J, Armstrong E (2017) A multi-scale highresolution analysis of global sea surface temperature. Remote Sens Environ 200:154-169

Coma R, Ribes M, Serrano E, Jiménez E, Salat J, Pascual J (2009) Global warming-enhanced stratification and mass mortality events in the Mediterranean. PNAS 106:6176-6181. https://doi.org/10.1073/ pnas.0805801106

Criado-Aldeanueva F, Vera JDR, García-Lafuente J (2008) Steric and mass-induced Mediterranean Sea level trends from 14 years of altimetry data. Glob Planet Chang 60:563-575. https://doi.org/10. 1016/j.gloplacha.2007.07.003

De Luis M, González-Hidalgo JC, Longares LA, Štepánek P (2009) Seasonal precipitation trends in the Mediterranean Iberian Peninsula in second half of 20th century. Int J Climatol 29:13121323. https://doi.org/10.1002/joc. 1778

De Luis M, Brunetti M, González-Hidalgo JC, Longares LA, MartinVide J (2010) Changes in seasonal precipitation in the Iberian Peninsula during 1946-2005. Glob Planet Chang 74:27-33. https:// doi.org/10.1016/j.gloplacha.2010.06.006

Donlon CJ, Martin M, Stark JD, Roberts-Jones J, Fiedler E, Wimmer W (2012) The operational sea surface temperature and sea ice analysis (OSTIA) system. Remote Sens Environ 116:140-158

Font J, Salat J, Tintoré J (1988) In: Minas HJ, Nival P (eds) Permanent features of the circulation in the Catalan Sea, vol 9. Pelagic Mediterranean Oceanography; Oceanologica Acta, pp 51-57

Font J, Puig P, Salat J, Palanques A, Emelianov M (2007) Sequence of hydrographic changes in NW Mediterranean deep water due to the exceptional winter of 2005. Sci Mar 71(2):339-346

Ganachaud A, Wunsch C, Marotzke J, Toole J (2000) Meridional overturning and large-scale circulation of the Indian Ocean. J Geophys Res: Oceans 105(C11):26117-26134. https://doi.org/10. 1029/2000JC900122

Goikoetxea N, Borja A, Fontán A, González M, Valencia V (2009) Trends and anomalies in sea-surface temperature, observed over the last 60 years, within the southeastern Bay of Biscay. Contin Shelf Res 29:1060-1069

Gomis D, Ruiz S, Sotillo MG, Álvarez-Fanjul E, Terradas J (2008) Low frequency Mediterranean Sea level variability: the contribution of atmospheric pressure and wind. Glob Planet Chang 63:215-229. https://doi.org/10.1016/j.gloplacha.2008.06.005

Jacobs WC (1942) On the energy exchange between sea and atmosphere. J Mar Res 5:37-66

Jordà G, Gomis D (2013) Reliability of the steric and mass components of Mediterranean Sea level as estimated from hydrographic gridded products. Geophys Res Lett 40:3655-3660. https://doi.org/10. 1002/grl.50718

Krahmann G, Schott F (1998) Longterm increases in western Mediterranean salinities and temperatures: anthropogenic and climatic sources. Geophys Res Lett 25:4209-4212. https://doi.org/10. 1029/1998GL900143

Marcos M, Tsimplis MN (2008) Coastal Sea level trends in Southern Europe. Geophys J Int 175:70-82. https://doi.org/10.1111/j.1365246X.2008.03892.x

Marcos M., Jordà G., Le Cozannett G. (2016). Sea level rise and its impacts on the Mediterranean. In: All Envi (ed) The Mediterranean region under climate change. A scientific update. IRD Éditions, Marseille: 265-275

Mertens C, Schott F (1998) Interannual variability of deep-water formation in the northwestern Mediterranean. J Phys Oceanogr 28:1410 1424

Nykjaer L (2009) Mediterranean Sea surface warming 1985-2006. Clim Res 39:11-17. https://doi.org/10.3354/cr00794

Pascual J, Salat J (2019) Oceanographic and meteorological observations from L'Estartit meteorological and oceanographical station in the NW Mediterranean. PANGAEA, https://doi.org/10.1594/ PANGAEA.902591

Reynolds RW, Chelton DB (2010) Comparisons of daily sea surface temperature analyses for 2007-08. J Clim 23:3545-3562

Reynolds RW, Smith TM, Liu C, Chelton DB, Casey KS, Schlax MG (2007) Daily high-resolution-blended analyses for sea surface temperature. J Clim 20:5473-5496

Rixen M, Beckers JM, Levitus S, Antonov J, Boyer T, Maillard C, Fichaut M, Balopoulos E, Iona S, Dooley H, Garcia MJ, Manca B, Giorgetti A, Manzella GMR, Mikhailov N, Pinardi N, Zavatarelli M (2005) The Western Mediterranean Deep Water: a proxy for climate 
change. Geophys Res Lett 32:L12608. https://doi.org/10.1029/ 2005GL022702

Schoreder K, Chiggiato J, Josey SA, Borghini M, Aracri S, Sparnocchia S (2017) Rapid response to climate change in a marginal sea. Sci Rep 7:4065. https://doi.org/10.1038/s41598-017-04455-5

Skliris N, Sofianos SS, Gkanasos A, Mantziafou A, Versatis V, Axaopoulos P, Lascaratos A (2012) Decadal scale variability of sea surface temperatura in the Mediterranean Sea in relation to atmospheric variability. Ocean Dyn 62:13-30. https://doi.org/10. 1007/s10236-011-0493-5

Sparnocchia S., Manzella G.M.R., La Violette P.E. (1994) The interannual and seasonal variability of the MAW and LIW core properties in the Western Mediterranean Sea. In: seasonal and interannual variability of the Western Mediterranean Sea. P.E. La Viollette (Ed.). Coast Estuar Stud, 46: 177-194

Sverdrup HU, Johnson MW, Fleming RH (1942) The oceans, their physics, chemistry and general biology. Prentice-Hall, New York

Tsimplis MN, Baker TF (2000) Sea level drop in the Mediterranean Sea: an indicator of deep water salinity and temperature changes? Geophys Res Lett 27:1731-1734. https://doi.org/10.1029/ 1999GL007004

Vargas-Yáñez M, Salat J, Fernández de Puelles ML, López-Jurado JL, Pascual J, Ramírez T, Cortés D, Franco I (2005) Trends and time variability in the northern continental shelf of the western Mediterranean. J Geophys Res 110:C10019. https://doi.org/10. 1029/2004JC002799
Vargas-Yáñez M, Moya F, Tel E, García-Martínez MC, Guerber E, Bourgeon M (2009) Warming and salting of the Western Mediterranean during the second half of the XX century: inconsistencies, unknowns and the effect of data processing. Sci Mar 73:728. https://doi.org/10.3989/scimar.2009.73n1007

Vargas-Yáñez M, Moya F, García-Martínez MC, Tel E, Zunino P, Plaza F, Salat J, Pascual J, López-Jurado JL, Serra M (2010) Climate change in the Western Mediterranean Sea 1900-2008. J Mar Syst 82:171176. https://doi.org/10.1016/j.jmarsys.2010.04.013

Vargas-Yáñez M, García-Martínez MC, Moya F, Balbin R, López-Jurado JL, Serra M, Zunino P, Pascual J, Salat J (2017) Updating temperature and salinity mean values and trends in the Western Mediterranean: RADMED project. Prog Oceanog 157:27-46. https://doi.org/10.1016/j.pocean.2017.09.004

von Schuckmann K, Le Traon PY, Álvarez-Fanjul E et al (2016) The Copernicus marine environment monitoring service ocean state report. J Operational Oceanography 9(sup2):s235-s320. https://doi. org/10.1080/1755876X.2016.1273446

von Schuckmann K. Le Traon P.Y., Smith N., Pascual A., Brasseur P., Fennel K., Djavidnia S. (Eds) (2018). Copernicus marine service ocean state report, J. Operational Oceanography, 11: sup1, S1S142, doi: https://doi.org/10.1080/1755876X.2018.1489208

WOCE (1988) WOCE implementation plan. Detailed requirements and scientific background. WCRP Series, 11, Geneva (Switzerland), $317 \mathrm{p}$ 